\title{
The Effect of Columns Configuration on High-rise Building Using Performance-based Design
}

\author{
Taufiq Rochman ${ }^{1, *}$, Nawir Rasidi $^{1}$, Sumardi $^{1}$, Evi Nur Cahya ${ }^{2}$, Andri Priyanto $^{3}$ \\ ${ }^{1}$ Civil Engineering Lecturer, State Polytechnic of Malang, Jl. Soekarno-Hatta, No.9. East Java 65141, Indonesia \\ ${ }^{2}$ Water Resources Engineering Lecturer, Brawijaya University 65145, Indonesia \\ ${ }^{3}$ Construction Engineering Management Student, Civil Engineering, State Polytechnic of Malang, Indonesia
}

Received September 27, 2020; Revised October 27, 2020; Accepted November 29, 2020

\section{Cite This Paper in the following Citation Styles}

(a): [1] Taufiq Rochman, Nawir Rasidi, Sumardi, Evi Nur Cahya, Andri Priyanto, "The Effect of Columns Configuration on High-rise Building Using Performance-based Design," Civil Engineering and Architecture, Vol. 8, No. 6, pp. 1144 1166, 2020. DOI: 10.13189/cea.2020.080601.

(b): Taufiq Rochman, Nawir Rasidi, Sumardi, Evi Nur Cahya, Andri Priyanto (2020). The Effect of Columns Configuration on High-rise Building Using Performance-based Design. Civil Engineering and Architecture, 8(6), 1144 1166. DOI: 10.13189/cea.2020.080601.

Copyright $\mathrm{C} 2020$ by authors, all rights reserved. Authors agree that this article remains permanently open access under the terms of the Creative Commons Attribution License 4.0 International License

\begin{abstract}
An important point of seismic assessment is the judgment of performance limit, which is ascertaining safety framework as building life. Because the higher a multi-story building was built, the higher the risk to the earthquake loads will be. In this paper, a description of column configuration in particular performance-based procedures used for assessing of associated tall buildings is proposed because the columns' size and its configuration strongly affect the performance of the seismic structural response. This paper is aimed to determine the column's size and its proper configuration associated for seismic resistance building structures. Five-building types were modeled using various column sizes and configurations. The pushover analysis from SAP2000 was used to obtain deformation capacity. Hence, the capacity spectrum method ATC-40 and displacement coefficient method FEMA 356 were implemented in order to get the performance points of each building model. The performance evaluation results show that all structural models have a level of performance that is better than maximum expectations, which are on the IO (Immediate Occupancy) performance level. Both building structural models $\mathrm{C}$ and $\mathrm{E}$ provide the largest deformation capacity, which is able to achieve displacement targets of up to $1.6 \mathrm{~m}$. However, the structure's deformation capacity is greatly affected by the column size and portal structure configuration. The capacity curve from pushover analysis shows that the largest deformation capacity is achieved by medium columns size with a target-drift up to $3 \%$.
\end{abstract}

Keywords Columns Configuration, Performance-based Design, Pushover Analysis, Structural Configuration, High-rise Building

\section{Introduction}

Columns are such a complex element due to its capability to overcome axial, shear forces and moment especially in the seismic condition. They play an important role in a building, hence the failure in a column is a critical point that can cause the regarding floor damage and is also responsible for the total collapse of the entire structures.

Beam column joints in a reinforced concrete moment resisting frame are crucial zones for transfer of loads effectively between the connecting elements (i.e., beams and columns) in the structure. In normal design practice for gravity loads, the design check for joints is not critical and hence not warranted. But, the failure of reinforced concrete frames during many earthquakes has demonstrated heavy distress due to shear in the joints that culminated in the collapse of the structure [1].

A clear understanding of the seismic performance of reinforced concrete columns is very important in designing earthquake-resistant structures. The main cause of soft story-buildings to be more susceptible to earthquakes is the localization of seismic forces [2]. In performance-based 
design, columns are designed to maintain a certain level of damage under the influence of the load applied to resist collapse. The level of damage in the column is usually related to moment capacity, drift capacity ratio, and drift ratio during yielding conditions.

In the performance-based design, the column stiffness initial estimation will greatly affect the load capacity, deformation demands, and dynamic response characteristics. In addition, the structural configuration model applied also impacts the drift ratio capacity and the structural displacement ductility.

Drift ratio capacity and displacement ductility are very important parameters in performance-based design as they represent the expected lateral deformation when reaching a certain level of strength damage. This research intends to get the best drift ratio capacity and displacement ductility based on various columns cross-section sizes and structural configurations.

Conforming to the objectives and criteria for seismic performance, the right method was used to produce an effective and efficient design. In this paper, the reinforcement concrete analysis of a 15 -story building model was conducted to study the effect of column cross-section size on the structural performance characteristics of drift ratio capacity and displacement ductility.

Nonlinear Static Procedure (NSP) of analysis also known as Pushover Analysis (PoA) is a simple method for prediction of non-linear behavior of the structure under seismic loads [3]. Pushover analysis is considered a step forward from the use of linear analysis, since they are based on a more accurate estimate of yielding within the structure, instead of assumed and uniform ductility [2]. While another researcher [4] studied the nonlinear static pushover analysis using displacement-based adaptive analysis. They evaluated the performance of 6,9,12 and 15 story RC moment-resisting frame and they stated that displacement-based adaptive pushover analysis provides better results compared to static pushover analysis. Another researcher [5] and [6] improved displacement-based adaptive pushover, and they performed its procedure based on factor modal combination rule. They concluded that the proposed methodology is capable of reproducing the peak dynamic responses, and results with very good accuracy.

Hence, the state of the arts of the pushover analysis development and regarding research around performance-based design are conducted by several researchers [6]; [2]; [7]; [8]; [9]; [10]; [11]; [12]; [13], and the latest development is an enhanced modal pushover analysis by single-layer latticed shell structures performed by $\mathrm{Qu}$ [14] and [15]. And another work namely pushunder analysis is performed by [16] and compared to those pushover analyses for approximating seismic analysis.

Essentially, this paper simulates the design of special moment bearing frame structure systems with the Direct Displacement Based Design (DDBD) design procedure, which is then excitation of the static load incrementally charged on the structure according to the distribution of its first variance using pushover analysis method. The nonlinear response structure of the analysis results is then evaluated with the principles of performance-based evaluation. It's for determining the size of the columns with the most efficient and effective structure configuration model.

\section{Materials and Methods}

\subsection{Ductility Characteristics of Reinforcement Concrete}

Ductility is the general term that describes the ability of the structure or its components to provide resistance in the inelastic domain of response. It includes the ability to sustain large deformations and a capacity to absorb energy by hysteretic behavior, the characteristics that are vital to a building's survival during and after a large earthquake. This capability of sustaining a high proportion of their strength that ensures survival of buildings when a major earthquake imposes large deformation is the single most important property sought by the designer of buildings located in regions of significant seismicity [17], and ductility model depicted in Figure 1.

Indonesian Code SNI-03-1726-2002 defines the building structure ductility factor as the ratio between the maximum deviation of the structure due to the effect of the planned earthquake on the verge of collapse and the deviation of the building structure at the time of the first yielding as shown in Figure 2, where its value meets the following equation [18]:

$$
1.0 \leq \mu=\frac{\delta m}{\delta y} \leq \mu_{m}
$$

Where:

$\mu=$ ductility factor

$\delta m$ = Maximum deviation on the verge of collapse

$\delta y=$ Deviation at the first yielding 


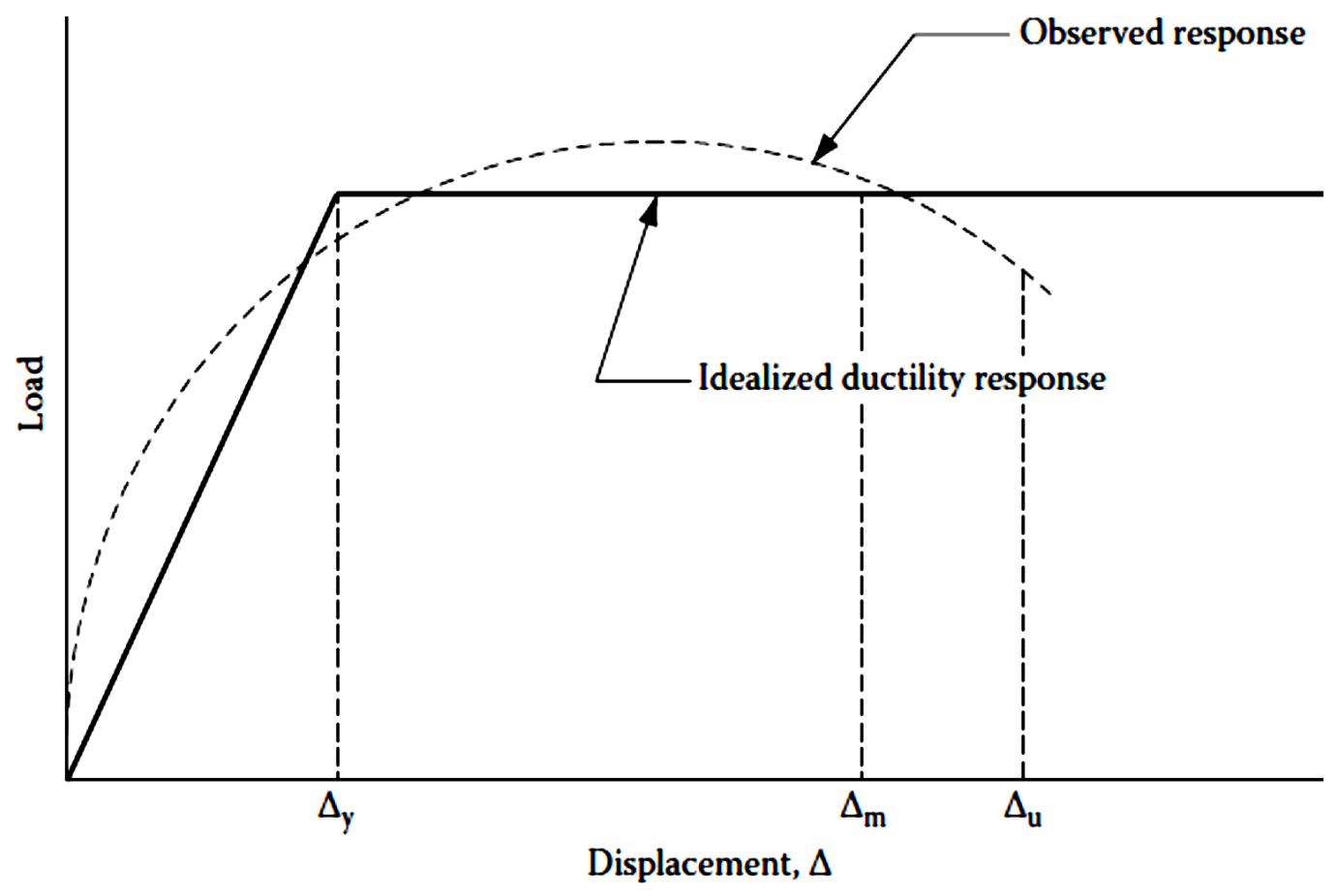

Source: [17]

Figure 1. Ductility model. The ability of the structure to provide resistance in the inelastic domain of response is termed "ductility." $\Delta u$ is the limit to ductility corresponding to a specified limit of strength degradation

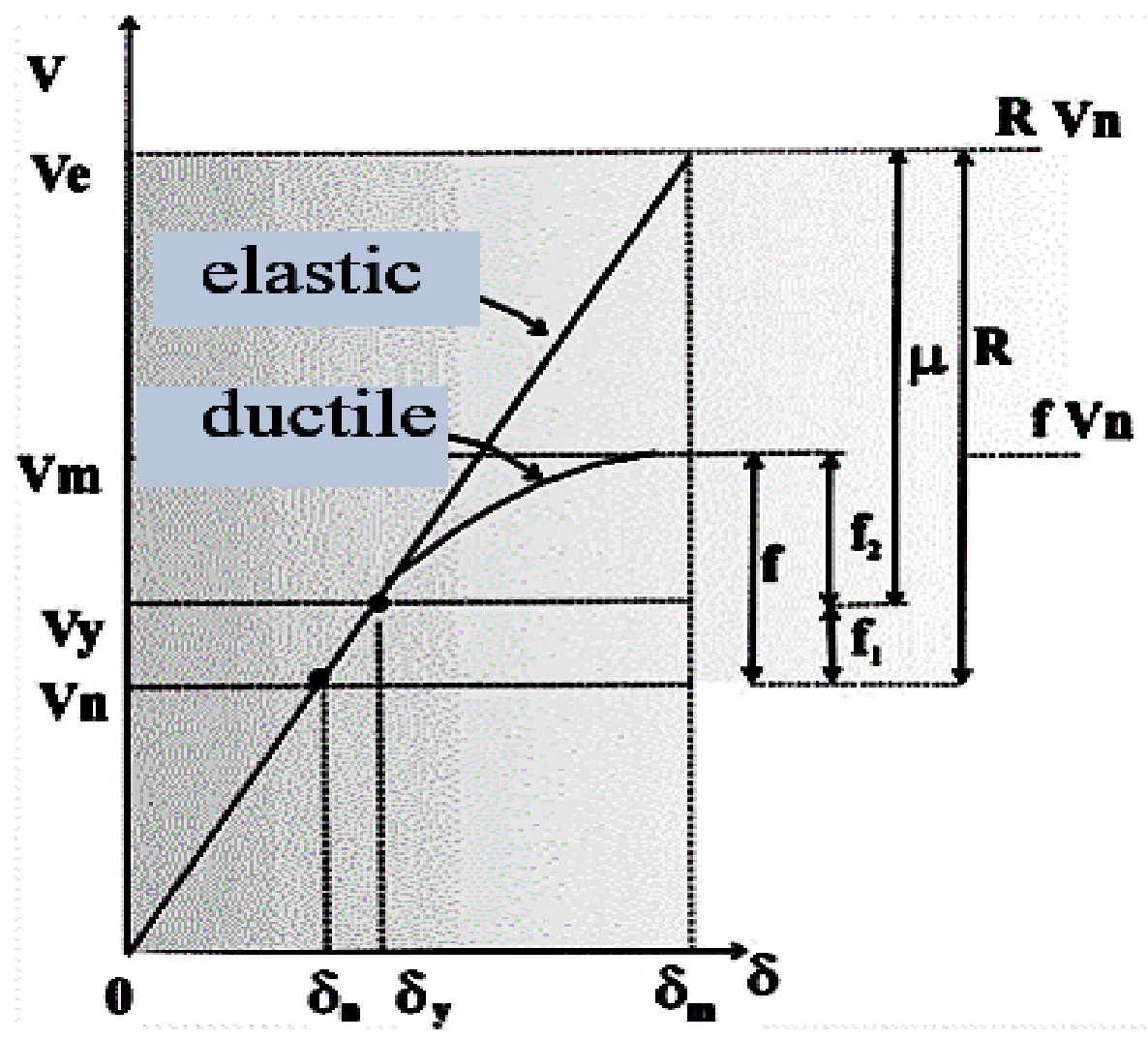




\subsection{Seismic Resistance Structural System}

The loads applied to the structure are divided into three categories, gravity, lateral, and other loads. The different parts of the building structure transfer the load into the foundation which in turn transfers it to the ground. The gravity resistance system uses the gravitational load of the structure. Lateral resistance system is a part of the structure that should resist against lateral load and transfer this load to the foundation [19]. Various types of lateral load supporting systems are depicted in Figure 3.

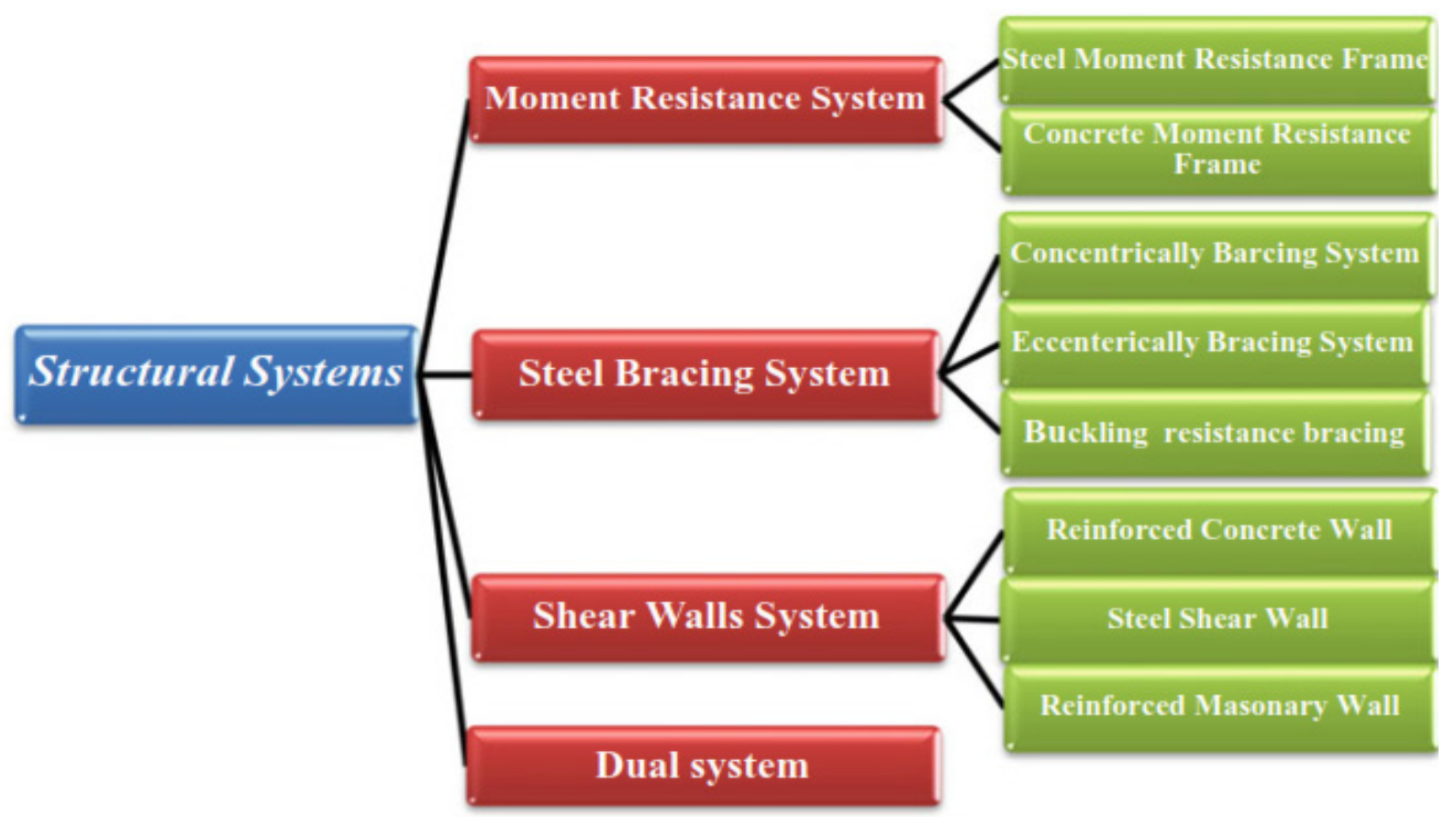

Source: [19]

Figure 3. Different types of lateral resistance structural

\subsection{Moment Resistance Frame: Gravity and Load Behavior}

Moment-resisting frames are commonly used in urban areas worldwide as the dominant mode of building construction. Moment frames (steel and reinforced concrete) have been used in seismic regions for a long time. However, documented poor performance of ordinary moment frames in past earthquakes warned the international community that this structural system required special design and detailing in order to warrant a ductile behavior when subjected to the action of strong earthquakes. Some of these initial efforts were transformed into recommendations that were included in design guidelines in different building codes worldwide as early as the late 1970s [20].

The behavior of the frame against a moment that is subject to gravity and lateral load are shown in Figure 4 and Figure 5 respectively. The load is transferred to the beam and then through the column to the ground [19] and [21]. In these two figures, the internal forces diagrams are in $\mathrm{a}, \mathrm{b}, \mathrm{c}$ and d diagrams exhibiting deformation, moment, shear and axial response respectively.

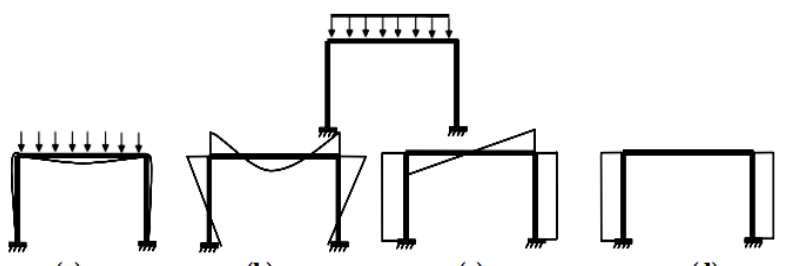

(a)

(b)

(c)

(d)

a) Deformation, b) moment, c) shear, d) axial diagram

Figure 4. Moment resistance frame under gravity load

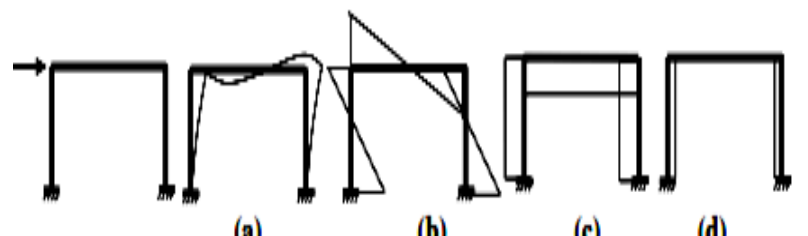

(a)

(b)

(c) (d)

Source: [19]

Figure 5. Moment resistance frame under lateral load 


\subsection{Performance-based Design}

Structural performance describes the level of the building's response due to a seismic design load. The performance-based structural design is usually designed in accordance with the purpose and utility of a building, using economic consideration factors to retrofit the building after seismic occurs. Hence, the structure is designed by considering economic factors without compromising the safety of building users [22].

The performance-based seismic design goal is to ensure that performance objectives are well satisfied. That is, the structure will perform in the desired manner under various intensity of earthquake loading. According to the framework of performance-based design [23].

There are other reasons why the performance-based design of tall buildings has gathered momentum. The overwhelming majority of construction in the United States and worldwide consists of low-rise buildings. According to Portland Cement Association (2000), buildings with one to three floors represent $93 \%$ of floor area of construction in United States while buildings with 14 floors or more represent only $1 \%$ of floor area of construction [1].

\subsection{Structural Performance Level}

Quantification of structural performance level based on global criteria is proposed in the ATC-40 document, where the parameters used are building drift and inelastic drift shown in Table 1.

While the quantification parameters with local criteria are proposed in FEMA 356 [25] and FEMA 440 [26] where the parameters used are in the form of deformations at the scale of the elements. FEMA 303/NEHRP 1997 document recommends a form of assessment matrix related to structural performance expectations of earthquake risk and building importance factors, as shown in Figure 6 [24].

The deformation limits for different performance levels, as per ATC-40 [27], are specified in Table 1.

Table 1. ATC-40 Deformation limit at all Structural Performance Levels

\begin{tabular}{ccccc}
\hline \multirow{2}{*}{$\begin{array}{c}\text { Deformation } \\
\text { limit }\end{array}$} & \multicolumn{4}{c}{ Structural Performance Levels } \\
\cline { 2 - 5 } & $\begin{array}{c}\text { Immediate } \\
\text { Occupancy }\end{array}$ & $\begin{array}{c}\text { Damage } \\
\text { Control }\end{array}$ & $\begin{array}{c}\text { Life } \\
\text { Safety }\end{array}$ & $\begin{array}{c}\text { Structural } \\
\text { Stability }\end{array}$ \\
\hline Maximum & 0.01 & $0.01-0.02$ & 0.02 & $0.33 V_{\mathrm{i}} / P_{i}$ \\
\hline $\begin{array}{c}\text { Max } \\
\text { Inelastic }\end{array}$ & 0.005 & $0.005-0.015$ & - & - \\
\hline
\end{tabular}

Source: [27]

\section{OPERATIONAL IMMEDIATE OCCUPANCY

DESIGN E/Q (2/3 OF MCE) $\mathrm{T}=$ 500 YEARS
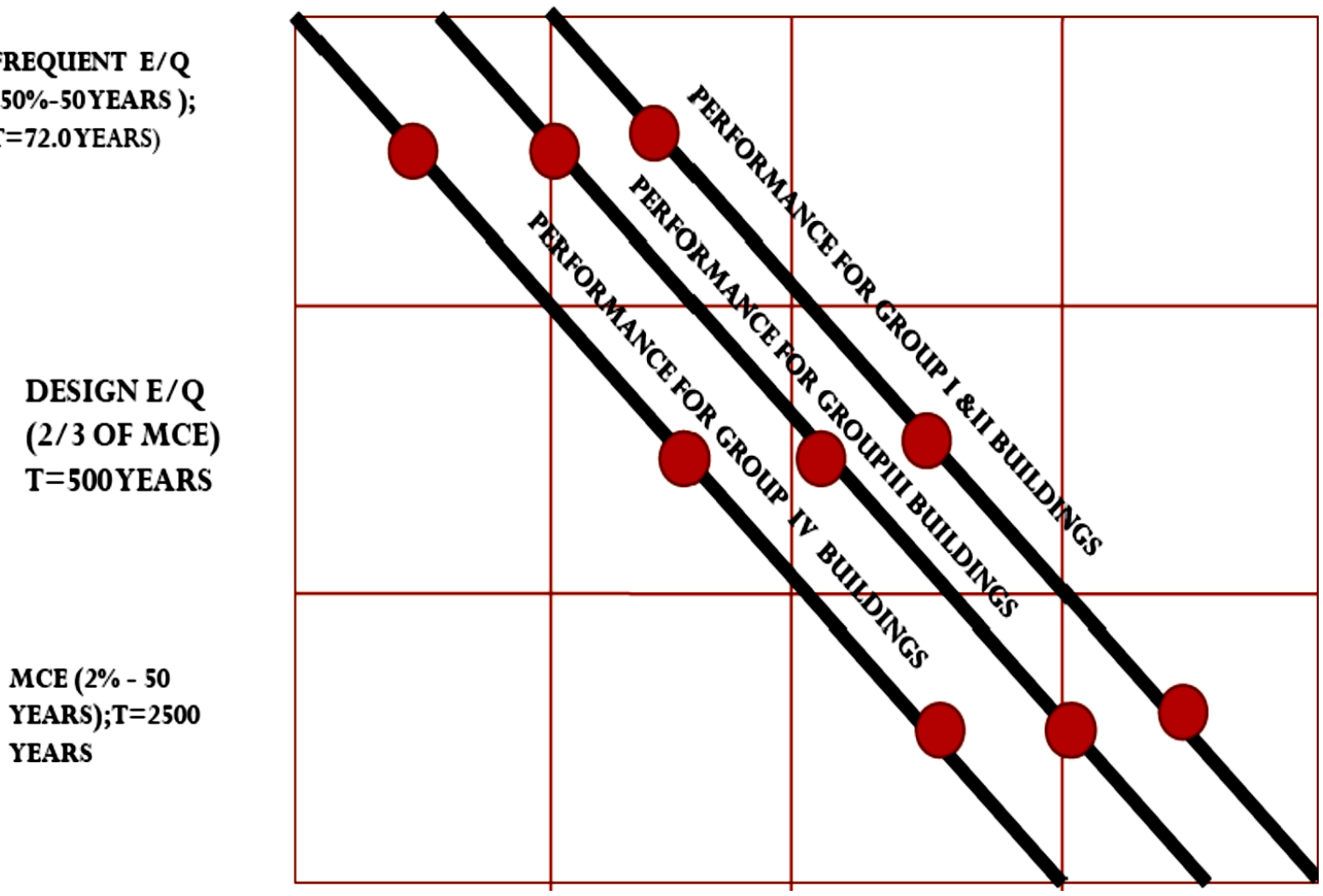


\subsection{Performance Point of ATC-40 Method}

The method for determining the performance level of structures based on ATC-40 is the capacity spectrum method. It describes the correlation of the demand response spectrum and capacity curves in the acceleration spectral to the displacement spectral or referred to as the Acceleration-Displacement Response Spectra (ADRS). The intersection between the capacity and demand spectrum is referred to as the performance point as shown in Figure 7 [27].

\subsection{Point Performance FEMA 356 Method}

The performance of building structures during an earthquake can be seen in Fig. 7. In general, the level of performance of FEMA 356 and ATC-40 is similar. While the hinge plastification mechanism the structural elements have been included in the FEMA 356 as shown in Figure 8 [25].

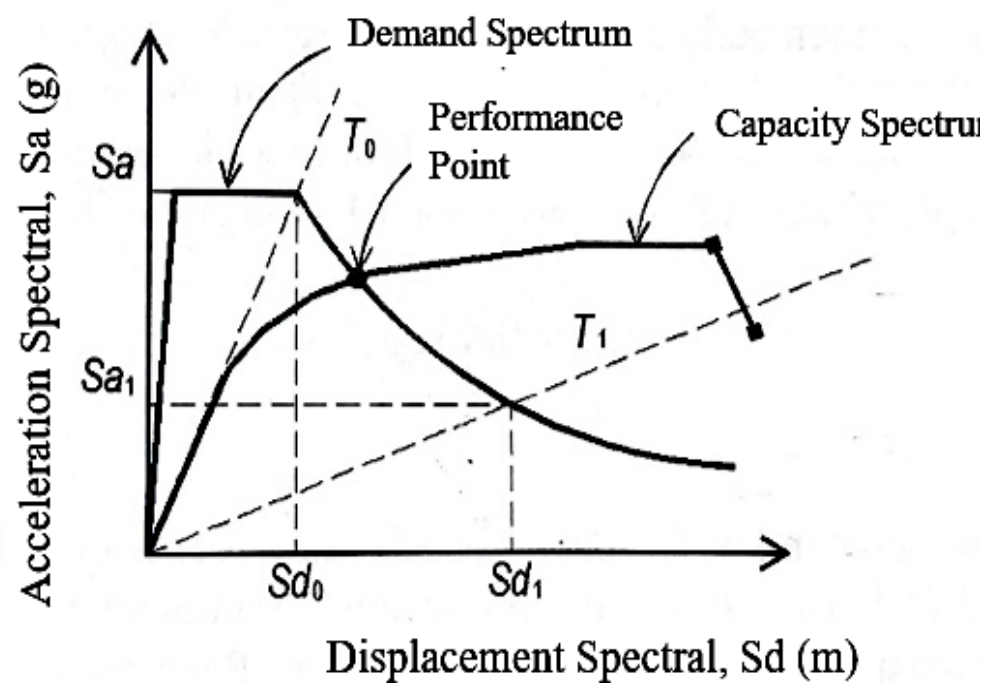

Source: [27]

Figure 7. Performance Point of ATC-40 Method

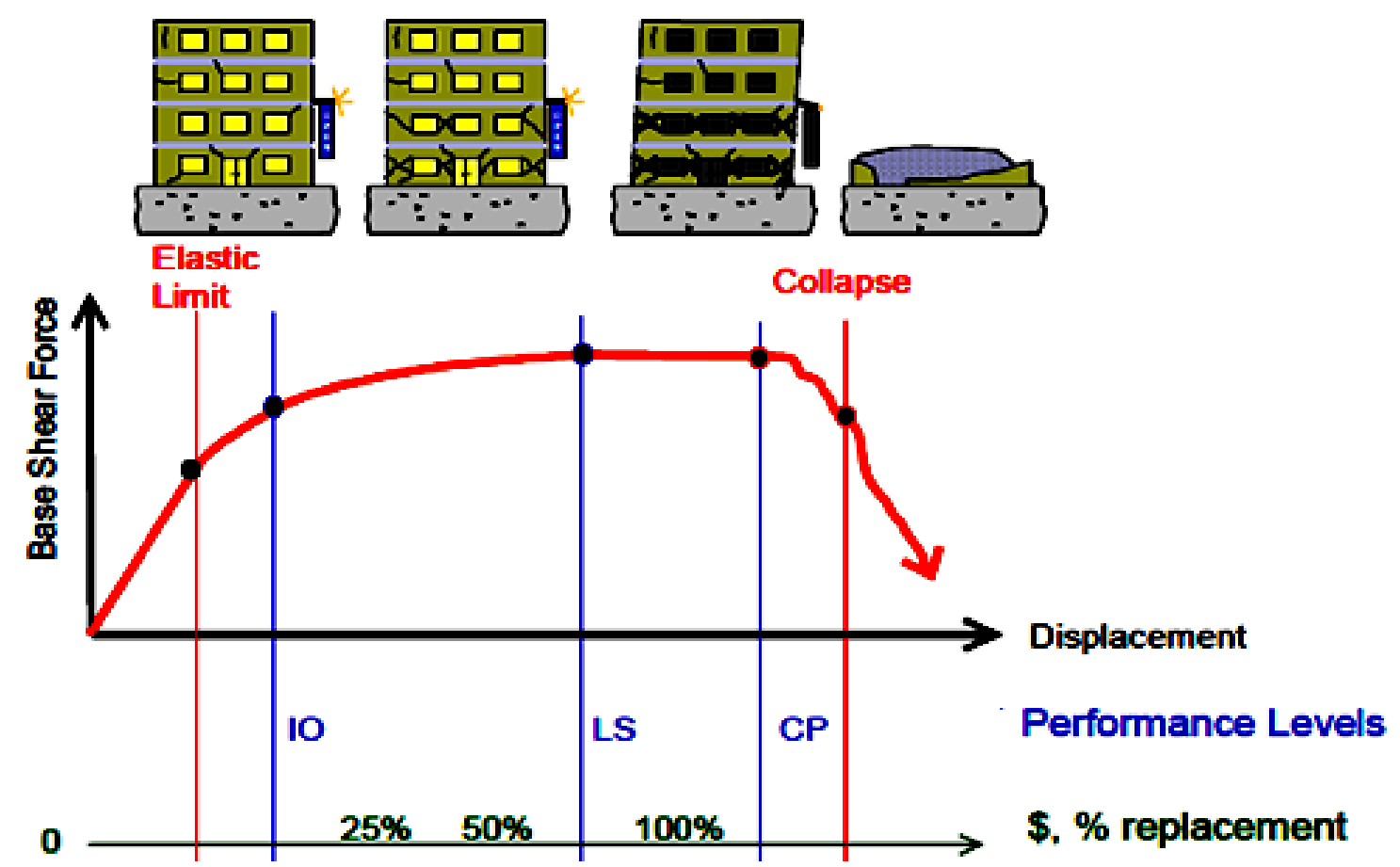

Source: [25]

Figure 8. Point of Performance FEMA Method 356 


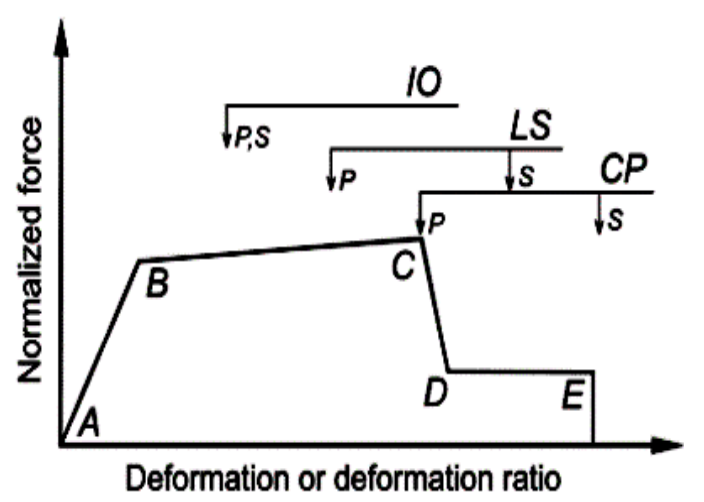

Source: [25]

Figure 9. The Hinge Plastification Mechanism of Plastic Hinge

(a) SDOF Simulation
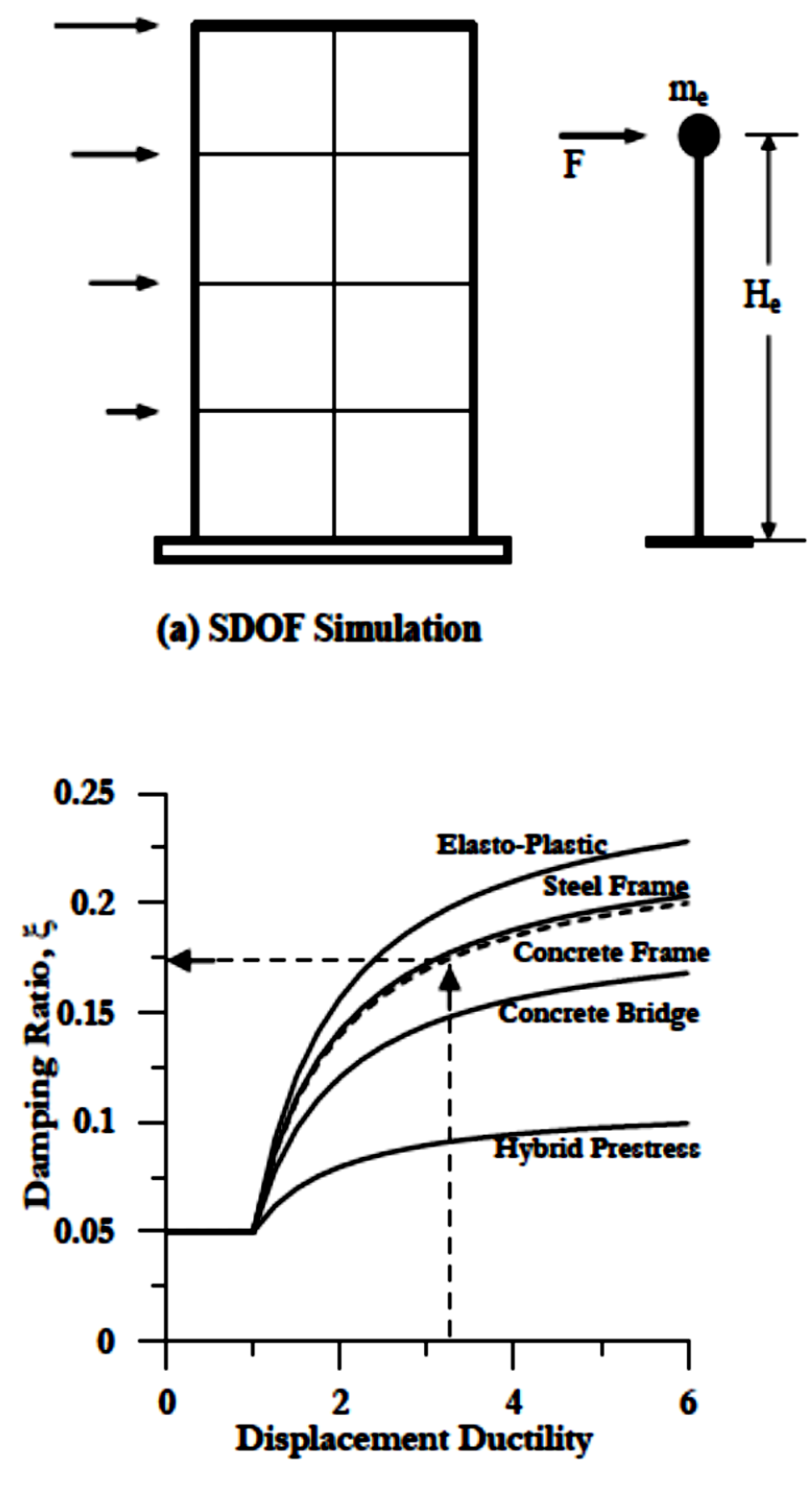

(c) Equivalent damping vs. ductility

$$
-7
$$

Source: [28]

\subsection{Direct Displacement Based Design Method (DDBD)}

Seismic loads will include forces and displacement in the structures. The ability of the structure to deform to an elastic response will be directly related to the rigidity of the system, but for structures at the time of the inelastic response, the relationship will be complicated, so it will depend on the momentary displacement as well as the history of displacement during the earthquake response.

Illustration of displacement-based design method is as shown in Figure 10 [28].

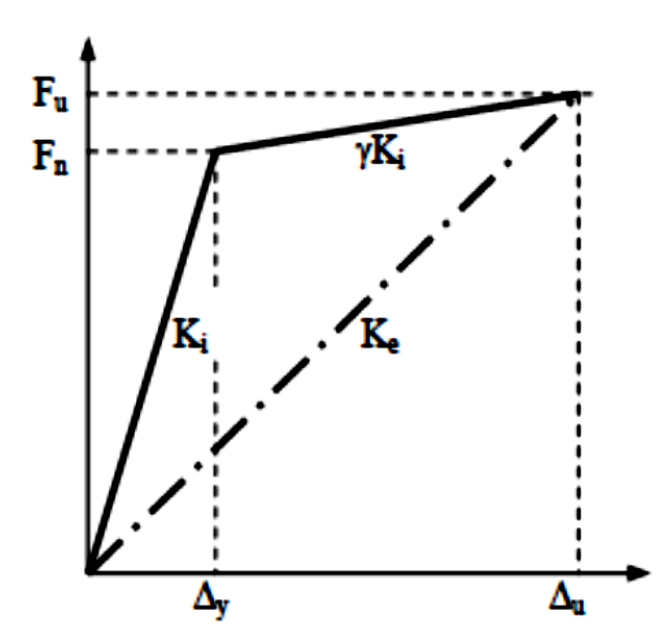

(b) Effective Stiffness $K_{\mathbf{e}}$

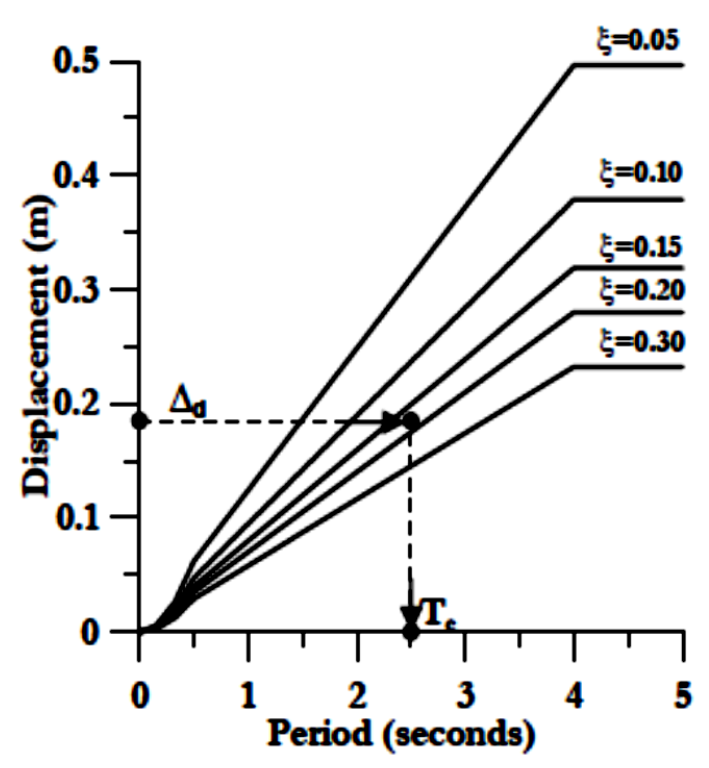

(d) Design Displacement Spectra 


\subsection{The Concept of Direct Displacement Based Design}

DDBD procedures are as follows [28] :

\subsubsection{Displacement Design Level (Story Drift)}

Calculation of the inelastic value of shape mode depends on the height of each $H_{i}$ level and the height of the floor plan $H_{n}$ which is given by (1) and (2):

$$
\delta_{\mathrm{\imath}}=\frac{H_{i}}{H_{n}} \text { for } \mathrm{n} \leq 4,
$$

Where $\delta_{l}$ :Displacement Design Level, $\mathrm{m}$

$H_{i}$ : Height on $\mathrm{i}^{\text {th }}$ floor level, $\mathrm{m}$

$H_{n}$ : Height on $\mathrm{n}^{\text {th }}$ floor level, $\mathrm{m}$

$n:$ Number of floors

\subsubsection{Equivalent Design of SDOF Displacement}

The SDOF displacement design can be computed by (3):

$$
\Delta_{d}=\frac{\sum_{i=1}^{n} m_{i} \Delta_{i}^{2}}{\sum_{i=1}^{n} m_{i} \Delta_{i}}
$$

Where $\Delta_{d}$ : Max. displacement of SDOF design, $\mathrm{m}$ $m_{i}$ : Mass at the $\mathrm{i}^{\text {th }}$ level, tons

$\Delta_{i:}$. Displacement on the $\mathrm{i}^{\text {th }}$ floor, $\mathrm{m}$

\subsubsection{Effective Mass}

The system effective mass $\left(m_{e}\right)$, can be set as (4):

$$
m_{e}=\frac{\sum_{i=1}^{n} m_{i} \Delta_{i}}{\Delta_{d}}
$$

\subsubsection{Effective Height}

The structural effective height $\left(H_{e}\right)$ can be found by (5):

$$
H_{e}=\frac{\sum_{i=1}^{n}\left(m_{i} \Delta_{i} h_{i}\right)}{\left(\sum_{i=1}^{n} m_{i} \Delta_{i}\right)}
$$

\subsubsection{Displacement Ductility Design}

The design factor of ductility can be computed by (6):

$$
\mu=\Delta_{d} / \Delta_{y}
$$

Where $\mu$ : System transfer ductility

$\Delta_{d}$ : Maximum displacement of SDOF design

$\Delta_{y}$ : Yield displ. of equivalent SDOF system

\subsubsection{Equivalent Viscous Attenuation}

The damping value for SDOF system can be set as (7) for concrete structures;

$$
\xi_{\mathrm{eq}}=0.05+0.565\left(\frac{\mu_{F}-1}{\mu_{F} \pi}\right)
$$

\subsubsection{Effective Period}

When the peak displacement response with inelastic attenuation, the effective period value of the SDOF system is calculated by converting the design spectrum response to the displacement spectra graph $\left(S_{d}\right)$ by the equivalent viscous damping level $\left(H_{e q}\right)$ as Figure $\left.10 \mathbf{d}\right)$.

\subsubsection{Effective Stiffness}

Effective stiffness at the maximum displacement response of the structure, $F / \Delta d$ can be determined by (8):

$$
K_{e}=\frac{4 \cdot \pi^{2} \cdot m_{e}}{T_{e}^{2}}
$$

\subsubsection{Base Shear Force Design}

The base shear force design for the MDOF system can be known using (9) in [28]:

$$
\mathrm{F}=\mathrm{V}_{\text {base }}=\mathrm{K}_{\mathrm{e}} \cdot \Delta_{\mathrm{d}}
$$

ASCE 7-10 gives the equation of the inelastic distribution of equivalent lateral seismic load (10) as follows [29] :

$$
F_{x}=C_{v x} \cdot V \quad C_{c x}=\frac{\mathrm{w}_{x} h_{i}^{k}}{\sum_{\mathrm{i}=1}^{\mathrm{n}} \mathrm{w}_{\mathrm{i}} h_{i}^{k}} \cdot \mathrm{V}
$$

FEMA 451 gives the exponent value, $\mathrm{k}$, for higher mode effects which can be seen in Figure 11 such in [30].

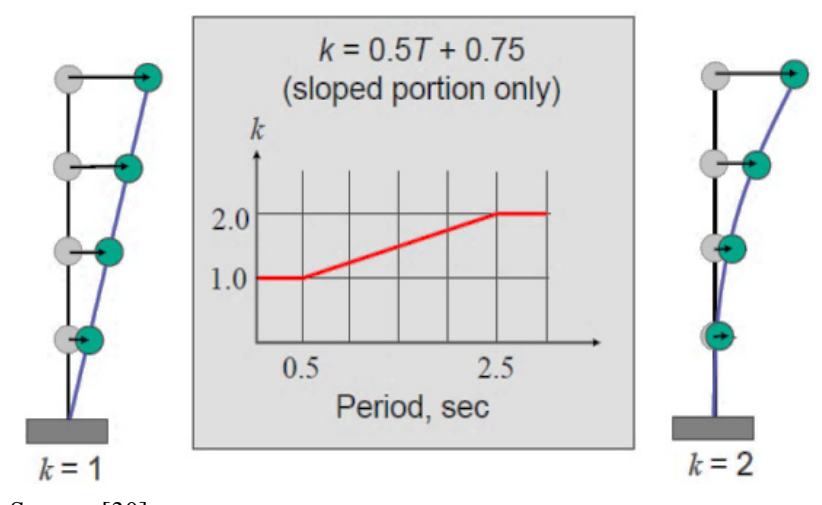

Source: [30]

Figure 11. k-accounts for higher mode effects

\section{Research Methods}

Taking into account all the theoretical basis previously described, this research is run according to the framework shown in Figure 12. This study examines 5 types of structural configurations that various sizes of the column cross-section. To obtain conclusions related to design procedures, the 5 models will be designed using the Direct Displacement Based Design (DDBD) method which is then excited incrementally charged with the pushover analysis method. The nonlinear response structure of the analysis results is then evaluated using the ATC-40 capacity spectrum method and FEMA356 displacement coefficient method. 


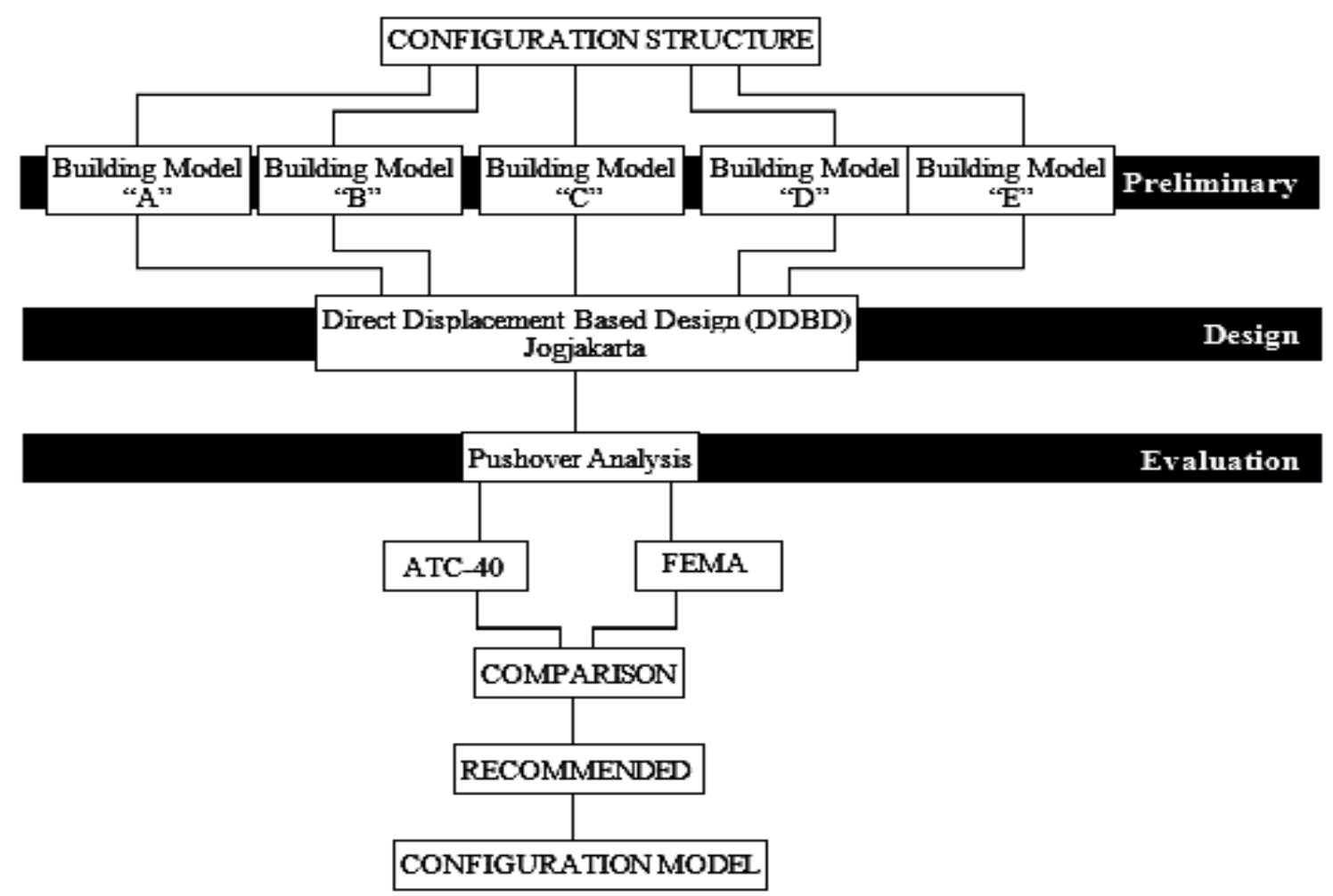

Figure 12. Research Conceptual Framework

\subsection{Column: Sizes and Configurations}

The structure is modeled in three dimensions which vary the size of the column cross-section such as in [31]. Determination of column size based on the ratio of the total area of the column cross-section to the floor area is a maximum of $2.6 \%$ and decreases $0.2 \%$ every three subsequent floors. For each building model, the column configuration is different so that it affects the number of columns in the building being designed. Thus, the size of the column elements can be used for each structure model.

\section{Discussion}

\subsection{Description of Studied Models}

A typical 15-story office building is modeled in this paper, with an elevation of the first floor of $4 \mathrm{~m}$, and the height of the next typical floor of $3.5 \mathrm{~m}$. The building is assumed to be in the Jogjakarta area and is designed with the Special Moment Resistant Frame System. The square architectural plan layout is used for this study, using a typical columns distance of $5 \mathrm{~m}$, while the span for the middle column varies, but all the models have equal columns total area. The structural model is made symmetrical so that the $\mathrm{X}$ direction and $\mathrm{Y}$ direction have the same span as shown in Figure 13.

A concrete strength of $f^{\prime} c=35 \mathrm{MPa}$ and steel rebar yield strength $f y=400 \mathrm{MPa}$ are used as main materials. Detailed dimensions and structural elements are shown in Table 2 through Table 8 and Figure 13.

The structure is analyzed based on the stiffness of the cross-section of the structural elements. 


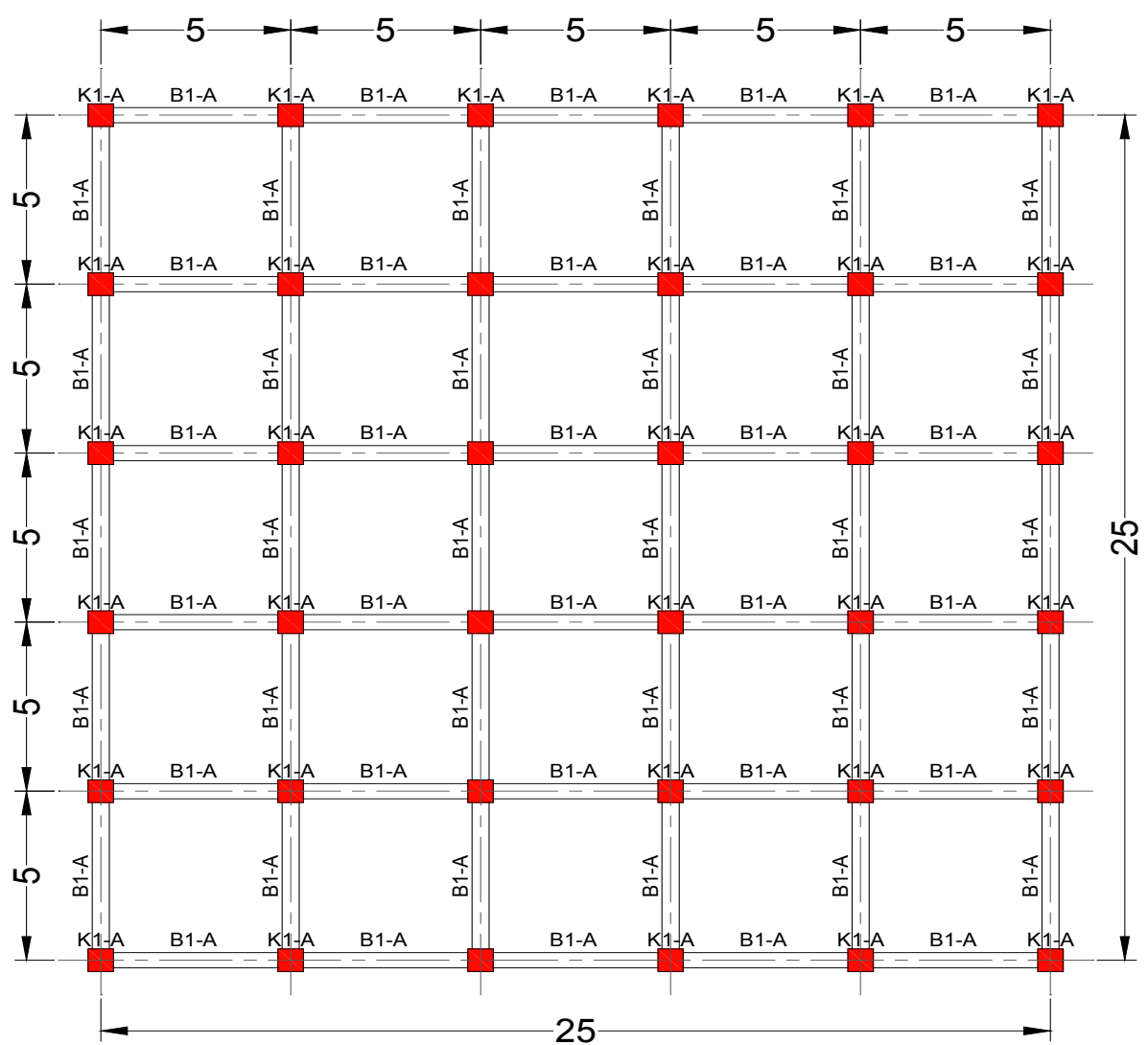

a)

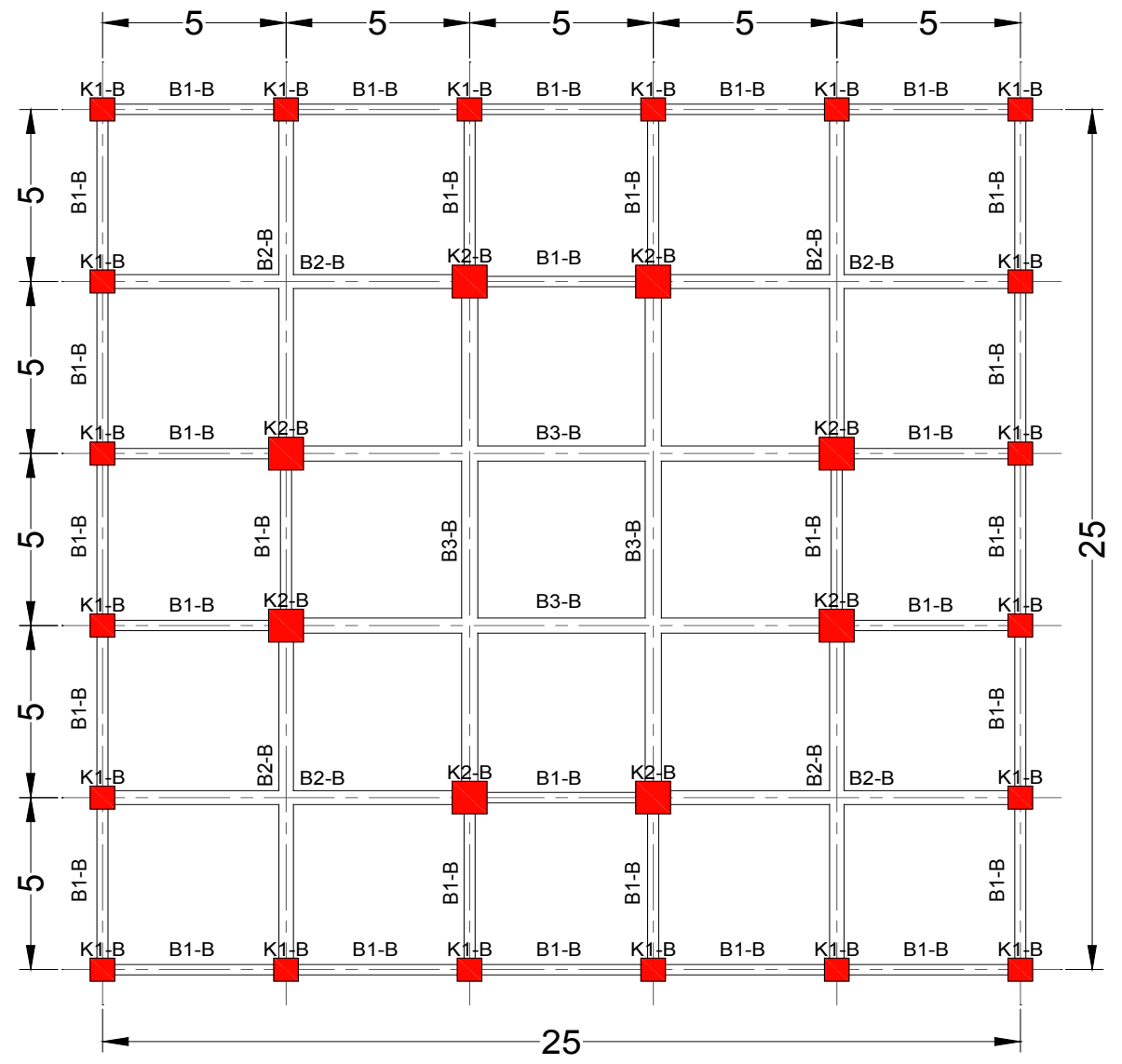

b) 


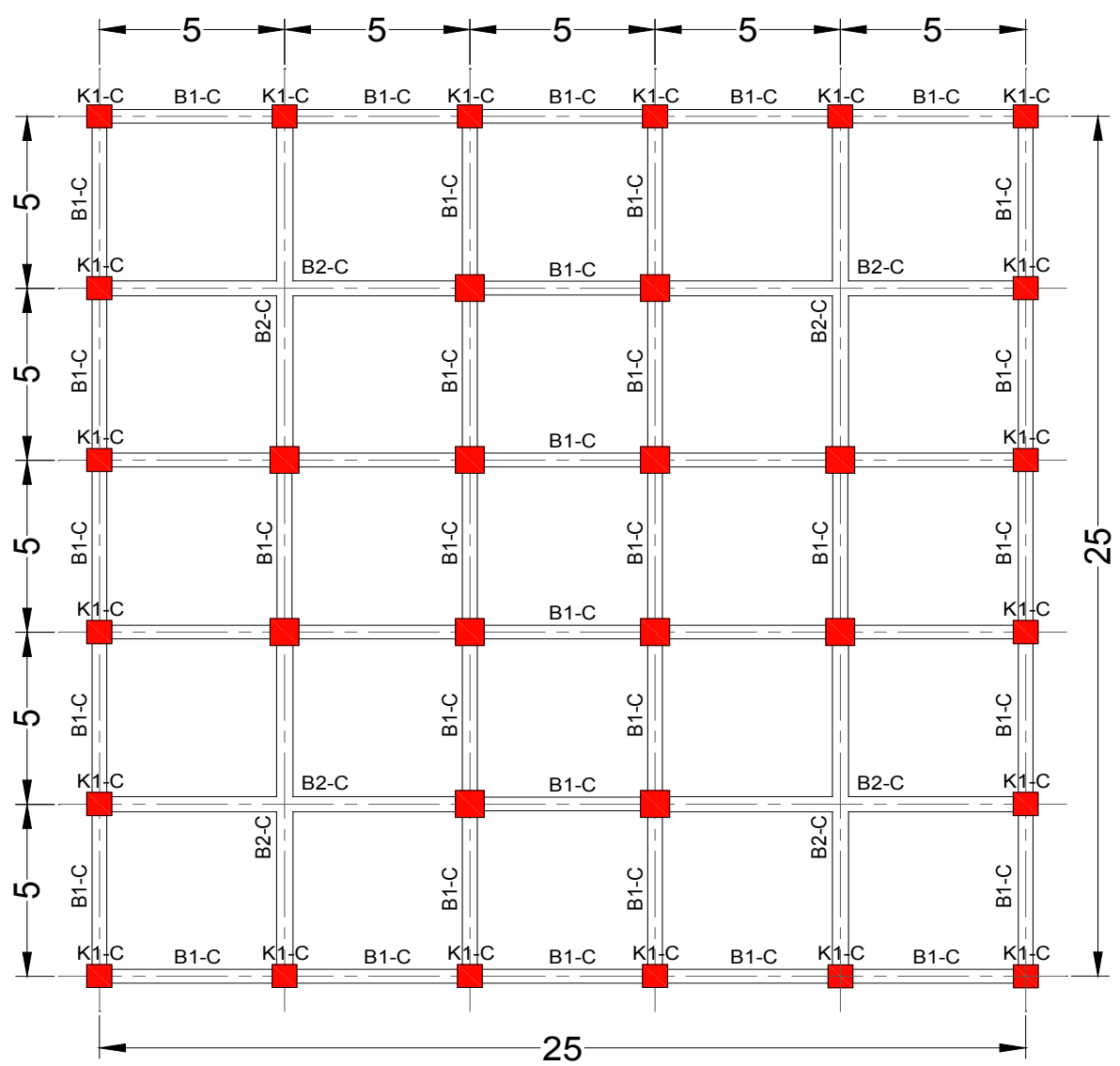

c)

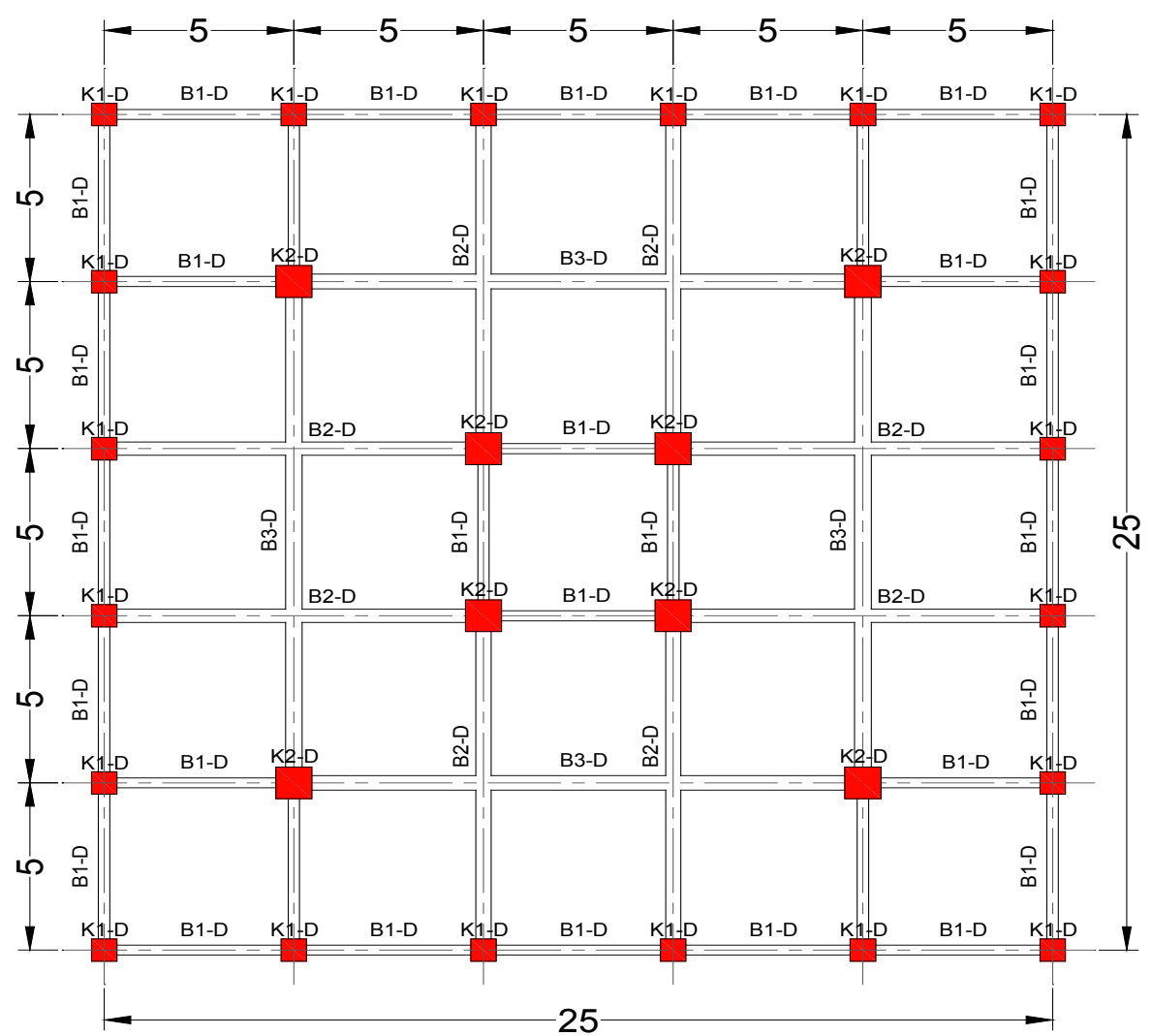




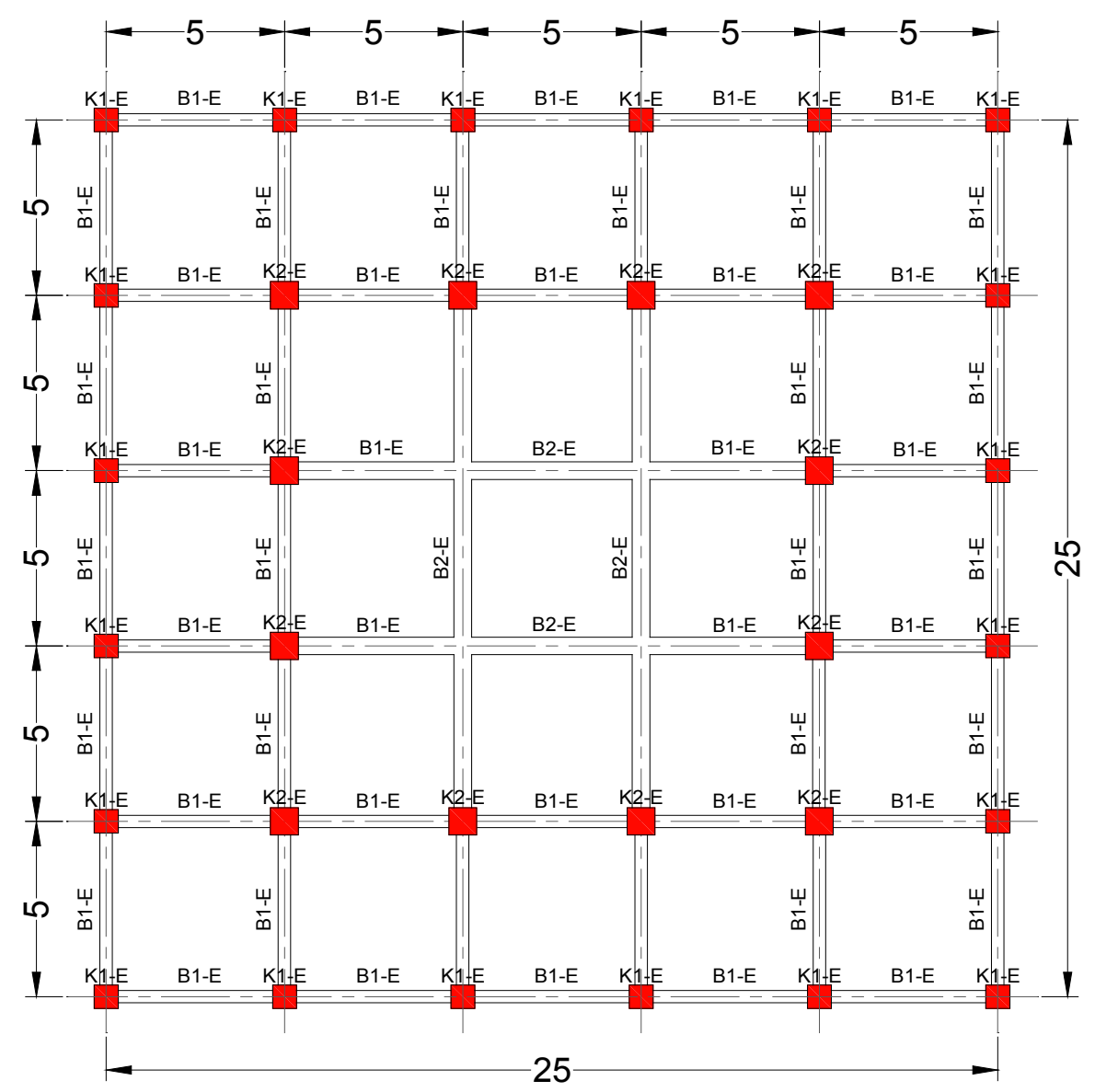

e)

Figure 13. Typical Structural Plan: a) Building Model A; b) Building Model B; c) Building Model C; d) Building Model D; e) Building Model E

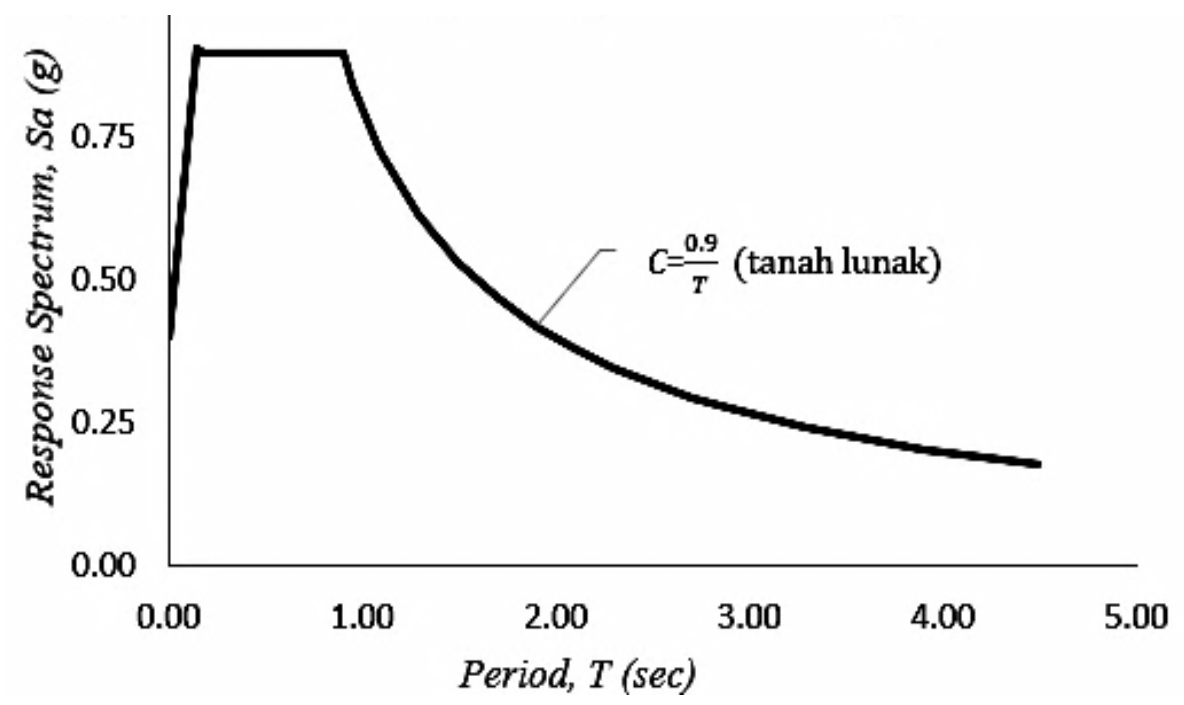

Figure 14. Response Spectra Design of Jogjakarta site class SE

\subsection{Structural Loading}

Gravity load refers to ASCE 7-10 Minimum Design Load for Buildings and Other Structure for Dead Load and live load [28]. As for the earthquake load taken in accordance with Indonesian Code SNI 1726: 2012 Procedures for
Earthquake Resilience Design for Buildings and Non-Buildings Structures in the Yogyakarta earthquake area shown in Figure 14.

The dimension of floor surrounding beams is set to be the same configuration in every floor for the sake of simplicity such described in Table $\mathbf{2}$ but column 
dimensions were varies following their height in Table 3 to Table 8 .

Table 2. Dimension of Floor Beam Elements 1-15 (roof)

\begin{tabular}{cccccc}
\hline \multirow{3}{*}{$\begin{array}{c}\text { Building } \\
\text { Model }\end{array}$} & Type & $\mathrm{h}$ & $\mathrm{d}$ & Beam length & Total \\
\cline { 2 - 6 } & & $(\mathrm{m})$ & $(\mathrm{m})$ & $(\mathrm{m})$ & (unit) \\
\hline & A $)$ & $(\mathrm{b})$ & $(\mathrm{c})$ & $(\mathrm{e})$ & $(\mathrm{f})$ \\
\hline \multirow{3}{*}{ B } & B1-A & 0.60 & 0.45 & 5.00 & 60 \\
\hline & B1-B & 0.60 & 0.30 & 5.00 & 32 \\
\hline & B2-B & 0.80 & 0.40 & 10.00 & 8 \\
\hline \multirow{2}{*}{ C } & B3-B & 1.00 & 0.44 & 15.00 & 4 \\
\hline \multirow{3}{*}{ D } & B1-C & 0.60 & 0.40 & 5.00 & 44 \\
\hline & B2-C & 0.80 & 0.44 & 10.00 & 8 \\
\hline & B1-D & 0.60 & 0.30 & 5.00 & 32 \\
\hline & B2-D & 0.80 & 0.40 & 10.00 & 8 \\
\hline \multirow{2}{*}{ E } & B3-D & 1.00 & 0.44 & 15.00 & 4 \\
\hline & B1-E & 0.60 & 0.35 & 5.00 & 48 \\
\hline & B2-E & 1.00 & 0.50 & 15.00 & 4 \\
\hline
\end{tabular}

Table 3. Column dimension of $1^{\text {st }}$ Floor, using $2.6 \%$ Ratio

\begin{tabular}{|c|c|c|c|c|c|}
\hline \multirow{3}{*}{$\begin{array}{c}\text { Building } \\
\text { Model }\end{array}$} & \multirow{2}{*}{ Type } & $h$ & $\mathrm{~d}$ & Height & Total \\
\hline & & $(\mathrm{m})$ & (m) & (m) & (unit) \\
\hline & (a) & (b) & (c) & (e) & (f) \\
\hline A & K1-A & 0.67 & 0.67 & 4.00 & 36 \\
\hline \multirow{2}{*}{ B } & K1-B & 0.67 & 0.67 & 4.00 & 20 \\
\hline & K2-B & 0.95 & 0.95 & 4.00 & 8 \\
\hline \multirow{2}{*}{$\mathrm{C}$} & K1-C & 0.67 & 0.67 & 4.00 & 20 \\
\hline & $\mathrm{K} 2-\mathrm{C}$ & 0.78 & 0.78 & 4.00 & 12 \\
\hline \multirow{2}{*}{$\mathrm{D}$} & K1-D & 0.67 & 0.67 & 4.00 & 20 \\
\hline & K2-D & 0.95 & 0.95 & 4.00 & 8 \\
\hline \multirow{2}{*}{ E } & K1-E & 0.67 & 0.67 & 4.00 & 20 \\
\hline & $\mathrm{K} 2-\mathrm{E}$ & 0.78 & 0.78 & 4.00 & 12 \\
\hline
\end{tabular}

Table 4. Column dimension of $2^{\text {nd }}$ and $3^{\text {rd }}$ floors, using $2.6 \%$ Ratio

\begin{tabular}{|c|c|c|c|c|c|}
\hline \multirow{3}{*}{$\begin{array}{l}\text { Building } \\
\text { Model }\end{array}$} & \multirow{2}{*}{ Type } & $h$ & $\mathrm{~d}$ & Height & Total \\
\hline & & $(\mathrm{m})$ & (m) & (m) & (unit) \\
\hline & (a) & (b) & (c) & (e) & (f) \\
\hline A & K1-A & 0.67 & 0.67 & 3.50 & 36 \\
\hline \multirow{2}{*}{ B } & K1-B & 0.67 & 0.67 & 3.50 & 20 \\
\hline & K2-B & 0.95 & 0.95 & 3.50 & 8 \\
\hline \multirow{2}{*}{$\mathrm{C}$} & K1-C & 0.67 & 0.67 & 3.50 & 20 \\
\hline & $\mathrm{K} 2-\mathrm{C}$ & 0.78 & 0.78 & 3.50 & 12 \\
\hline \multirow{2}{*}{ D } & K1-D & 0.67 & 0.67 & 3.50 & 20 \\
\hline & K2-D & 0.95 & 0.95 & 3.50 & 8 \\
\hline \multirow{2}{*}{ E } & K1-E & 0.67 & 0.67 & 3.50 & 20 \\
\hline & K2-E & 0.78 & 0.78 & 3.50 & 12 \\
\hline
\end{tabular}

The columns dimension lesser from top level were exaggerated in the bottom level to make sure that lower columns stiffer than those above adjacent columns following Table 3 to Table 8.
Table 5. Column Dimensions of $4^{\text {th }}$ and $5^{\text {th }}$ floors, using a $2.4 \%$ ratio

\begin{tabular}{cccccc}
\hline \multirow{2}{*}{$\begin{array}{c}\text { Building } \\
\text { Model }\end{array}$} & Type & $h$ & $\mathrm{~d}$ & Height & Total \\
\cline { 2 - 6 } & & $(\mathrm{m})$ & $(\mathrm{m})$ & $(\mathrm{m})$ & (unit) \\
\hline \multirow{2}{*}{$\mathrm{A}$} & K2 $)$ & $(\mathrm{b})$ & $(\mathrm{c})$ & $(\mathrm{e})$ & $(\mathrm{f})$ \\
\hline \multirow{2}{*}{$\mathrm{B}$} & K3-B & 0.65 & 0.65 & 3.50 & 36 \\
\cline { 2 - 6 } & K4-B & 0.91 & 0.91 & 3.50 & 8 \\
\hline \multirow{2}{*}{$\mathrm{C}$} & K3-C & 0.65 & 0.65 & 3.50 & 20 \\
\cline { 2 - 6 } & K4-C & 0.75 & 0.75 & 3.50 & 12 \\
\hline \multirow{2}{*}{$\mathrm{D}$} & K3-D & 0.65 & 0.65 & 3.50 & 20 \\
\cline { 2 - 6 } & K4-D & 0.91 & 0.91 & 3.50 & 8 \\
\hline \multirow{2}{*}{ E } & K3-E & 0.65 & 0.65 & 3.50 & 20 \\
\cline { 2 - 6 } & K4-E & 0.75 & 0.75 & 3.50 & 12 \\
\hline
\end{tabular}

Table 6. Column Dimensions of $7^{\text {th }}$ and $9^{\text {th }}$ floors, using a $2.2 \%$ Ratio

\begin{tabular}{|c|c|c|c|c|c|}
\hline \multirow{3}{*}{$\begin{array}{c}\text { Building } \\
\text { Model }\end{array}$} & \multirow{2}{*}{ Type } & $h$ & d & Height & Total \\
\hline & & $(\mathrm{m})$ & (m) & (m) & (unit) \\
\hline & (a) & (b) & (c) & (e) & (f) \\
\hline A & K3-A & 0.62 & 0.62 & 3.50 & 36 \\
\hline \multirow{2}{*}{ B } & K5-B & 0.62 & 0.62 & 3.50 & 20 \\
\hline & K6-B & 0.87 & 0.87 & 3.50 & 8 \\
\hline \multirow{2}{*}{ C } & K5-C & 0.62 & 0.62 & 3.50 & 20 \\
\hline & K6-C & 0.71 & 0.71 & 3.50 & 12 \\
\hline \multirow{2}{*}{ D } & K5-D & 0.62 & 0.62 & 3.50 & 20 \\
\hline & K6-D & 0.87 & 0.87 & 3.50 & 8 \\
\hline \multirow{2}{*}{$\mathrm{E}$} & K5-E & 0.62 & 0.62 & 3.50 & 20 \\
\hline & K6-E & 0.71 & 0.71 & 3.50 & 12 \\
\hline
\end{tabular}

Table 7. Column Dimensions of $10^{\text {th }}$ and $12^{\text {th }}$ floors, using a $2.0 \%$ Ratio

\begin{tabular}{|c|c|c|c|c|c|}
\hline \multirow{3}{*}{$\begin{array}{l}\text { Building } \\
\text { Model }\end{array}$} & \multirow{2}{*}{ Type } & $h$ & D & Height & Total \\
\hline & & (m) & (m) & (m) & (unit) \\
\hline & (a) & (b) & (c) & (e) & (f) \\
\hline A & K4-A & 0.59 & 0.59 & 3.50 & 36 \\
\hline \multirow{2}{*}{ B } & K7-B & 0.59 & 0.59 & 3.50 & 20 \\
\hline & K8-B & 0.83 & 0.83 & 3.50 & 8 \\
\hline \multirow{2}{*}{$\mathrm{C}$} & K7-C & 0.59 & 0.59 & 3.50 & 20 \\
\hline & $\mathrm{K} 8-\mathrm{C}$ & 0.68 & 0.68 & 3.50 & 12 \\
\hline \multirow{2}{*}{$\mathrm{D}$} & K7-D & 0.59 & 0.59 & 3.50 & 20 \\
\hline & K8-D & 0.83 & 0.83 & 3.50 & 8 \\
\hline \multirow{2}{*}{ E } & K7-E & 0.59 & 0.59 & 3.50 & 20 \\
\hline & K8-E & 0.68 & 0.68 & 3.50 & 12 \\
\hline
\end{tabular}


Table 8. Column Dimensions of $13^{\text {th }}$ and $15^{\text {th }}$ floors, using a $1.8 \%$ Ratio

\begin{tabular}{|c|c|c|c|c|c|}
\hline \multirow{3}{*}{$\begin{array}{c}\text { Building } \\
\text { Model }\end{array}$} & \multirow{2}{*}{ Type } & $h$ & D & Height & Total \\
\hline & & (m) & (m) & (m) & (unit) \\
\hline & (a) & (b) & (c) & (e) & (f) \\
\hline A & K5-A & 0.56 & 0.56 & 3.50 & 36 \\
\hline \multirow{2}{*}{ B } & K9-B & 0.56 & 0.56 & 3.50 & 20 \\
\hline & K10-B & 0.79 & 0.79 & 3.50 & 8 \\
\hline \multirow{2}{*}{$\mathrm{C}$} & K9-C & 0.56 & 0.56 & 3.50 & 20 \\
\hline & K10-C & 0.65 & 0.65 & 3.50 & 12 \\
\hline \multirow{2}{*}{ D } & K9-D & 0.56 & 0.56 & 3.50 & 20 \\
\hline & K10-D & 0.79 & 0.79 & 3.50 & 8 \\
\hline \multirow{2}{*}{$\mathrm{E}$} & K9-E & 0.56 & 0.56 & 3.50 & 20 \\
\hline & K10-E & 0.65 & 0.65 & 3.50 & 12 \\
\hline
\end{tabular}

The equal thickness of the plate elements was proposed as $12 \mathrm{~cm}$ thick for floors $1-14$ and $10 \mathrm{~cm}$ for 15 floors (roofs). So that the mass structure of all building models is similar as shown in the Figure 15.

\subsection{Design of Base Shear Forces using DDBD (Direct Displacement Based Design)}

The base shear force design can be described by the DDBD method for the frame system as proposed is as follows:

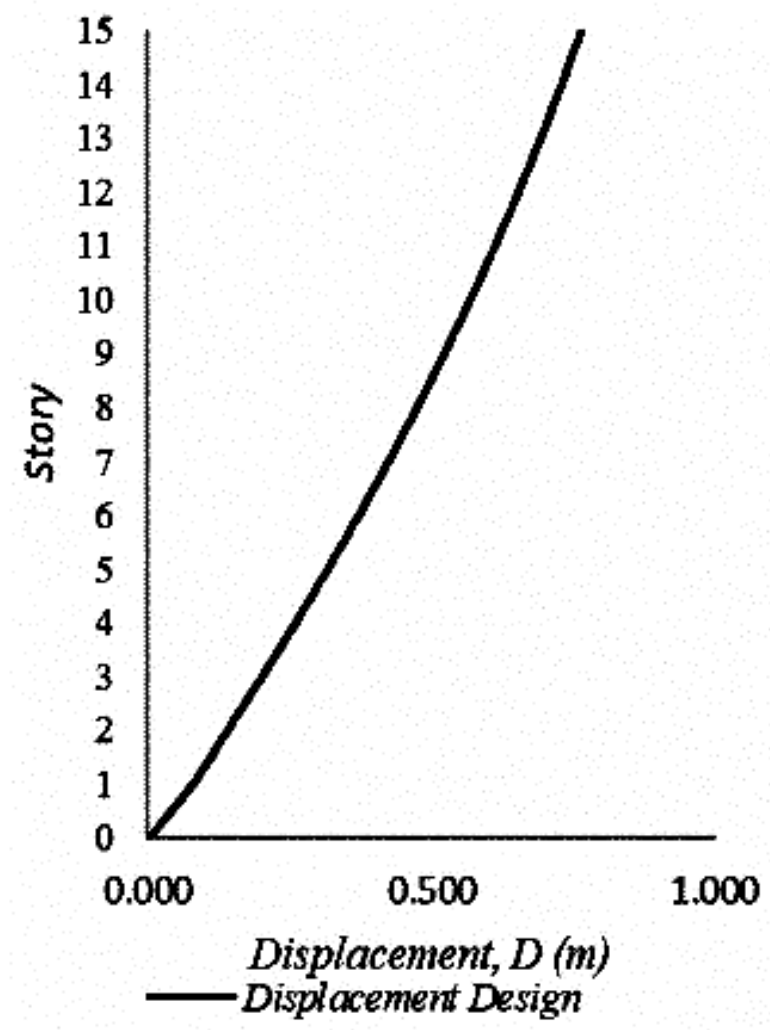

\subsubsection{Level Displacement Design (Story Drift)}

The level displacement design for all building models is identical, as shown in Figure 16.

\begin{tabular}{c|c|c|c|c|}
\hline 15 & 4146.23 & 243.75 & 1200.00 \\
14 & 4626.60 & 900.00 & 1650.00 \\
13 & 4626.60 & 900.00 & 1650.00 \\
12 & 4731.60 & 900.00 & 1650.00 \\
11 & 4731.60 & 900.00 & 1650.00 \\
10 & 4731.60 & 900.00 & 1650.00 \\
9 & 4836.60 & 900.00 & 1650.00 \\
8 & 4836.60 & 900.00 & 1650.00 \\
7 & 4836.60 & 900.00 & 1650.00 \\
6 & 4941.60 & 900.00 & 1650.00 \\
5 & 4941.60 & 900.00 & 1650.00 \\
4 & 4941.60 & 900.00 & 1650.00 \\
3 & 5046.60 & 900.00 & 1650.00 \\
2 & 5046.60 & 900.00 & 1650.00 \\
1 & 5241.60 & 900.00 & 1650.00 \\
base & 0.00 & 0.00 & 0.00 \\
Story & Self-Weight & Superimposed & Live Load \\
& & Dead Load & $(\mathrm{kN})$
\end{tabular}

Figure 15. Structural Load (self-weight, superimposed dead and live) for all building models

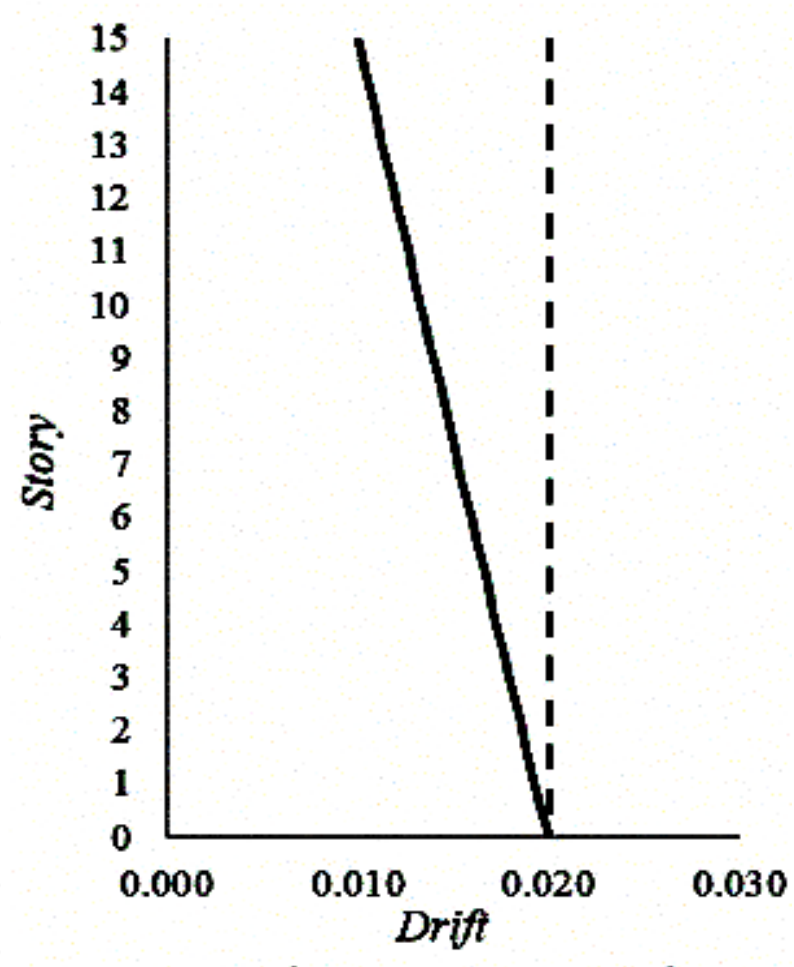

Drift Design - - - Drift Limit

a)

Figure 15. Level Displacement Design: a) Displacement Design; b) Drift Design 


\subsubsection{SDOF Displacement Design}

In this study, all buildings in the design have a similar building mass. Therefore, the design of the transfer of a single degree of freedom (SDOF) for each building model has equal value, which is computed by the following equation:

$$
\Delta_{\mathrm{d}}=\frac{\sum_{\mathrm{i}=1}^{\mathrm{n}} \mathrm{m}_{\mathrm{i}} \Delta_{\mathrm{i}}^{2}}{\sum_{\mathrm{i}=1}^{\mathrm{n}} \mathrm{m}_{\mathrm{i}} \Delta_{\mathrm{i}}}=\frac{2339.53}{4380.42}=0.534 \mathrm{~m}
$$

\subsubsection{Effective Height}

Effective height with an SDOF system for each building model has equal value, which is given by the following equation:

$$
\mathrm{H}_{\mathrm{e}}=\frac{\sum_{\mathrm{i}=1}^{\mathrm{n}}\left(\mathrm{m}_{\mathrm{i}} \Delta_{\mathrm{i}} \mathrm{h}_{\mathrm{i}}\right)}{\left(\sum_{\mathrm{i}=1}^{\mathrm{n}} \mathrm{m}_{\mathrm{i}} \Delta_{\mathrm{i}}\right)}=\frac{154189.9}{4380.42}=35.200 \mathrm{~m}
$$

\subsubsection{Effective Mass}

The effective mass with an SDOF system for each building model is computed by the following equation:

$$
\mathrm{m}_{\mathrm{e}}=\frac{\sum_{\mathrm{i}=1}^{\mathrm{n}} \mathrm{m}_{\mathrm{i}} \Delta_{\mathrm{i}}}{\Delta_{\mathrm{d}}}=\frac{4380.42}{0.534}=8201.690 \text { ton }
$$

\subsubsection{Equivalent Effective damping}

The ductility in the X-direction and Y-direction frames is calculated based on the net beam length $\left(\mathrm{L}_{\mathrm{b}}\right)$ and beam height $\left(\mathrm{H}_{\mathrm{b}}\right.$ ), and the value $\mathrm{M}_{1}=\mathrm{M}_{\mathrm{i}}$ (because all beams are designed so that the moment values are equal) as shown in Table 9.

Table 9. Lateral deflection, Ductility Design, and Effective Damping

\begin{tabular}{cccccc}
\hline \multirow{2}{*}{ Parameter } & \multicolumn{5}{c}{ Building } \\
\cline { 2 - 6 } & $\mathrm{A}$ & $\mathrm{B}$ & $\mathrm{C}$ & $\mathrm{D}$ & $\mathrm{E}$ \\
\hline$\Delta_{\boldsymbol{d}}$ & 0.534 & 0.534 & 0.534 & 0.534 & 0.534 \\
\hline$\Delta_{y}$ & 0.254 & 0.252 & 0.275 & 0.300 & 0.271 \\
\hline$\mu_{F}$ & 2.103 & 2.123 & 1.940 & 1.779 & 1.970 \\
\hline$\xi_{\text {eq }}$ & $14.6 \%$ & $14.7 \%$ & $13.9 \%$ & $13.0 \%$ & $14.0 \%$ \\
\hline
\end{tabular}

\subsubsection{Effective Period}

The effective period design is based on the spectra displacement $(\mathrm{Sd})$ graph at the level of damping which can be seen in Figure 16.

From the displacement spectra graph, as shown in Figure 16, it can be seen that the effective period of the structure at the level of damping is shown in Table 10.

Table 10. Effective Period at the Effective Damping of Each Building Model

\begin{tabular}{cccccc}
\hline \multirow{2}{*}{ Parameter } & \multicolumn{5}{c}{ Building } \\
\cline { 2 - 6 } & $\mathrm{A}$ & $\mathrm{B}$ & $\mathrm{C}$ & $\mathrm{D}$ & $\mathrm{E}$ \\
\hline Damping & $14.22 \%$ & $14.50 \%$ & $13.40 \%$ & $13.04 \%$ & $14.04 \%$ \\
\hline $\begin{array}{c}\text { Period } \\
\left(\mathrm{T}_{\mathrm{ef}}\right)\end{array}$ & $4.1 \mathrm{sec}$ & $4.1 \mathrm{sec}$ & $4.0 \mathrm{sec}$ & $4.0 \mathrm{sec}$ & $4.1 \mathrm{sec}$ \\
\hline
\end{tabular}

\subsubsection{Effective Stiffness}

Effective stiffness in each building model is computed by the following equation and tabulated in Table 11.

$$
\mathrm{K}_{\mathrm{e}}=\frac{4 \cdot \pi^{2} \cdot \mathrm{m}_{\mathrm{e}}}{\mathrm{T}_{\mathrm{e}}^{2}}
$$

Table 11. Effective Stiffness at the Effective Damping of Each Building Model

\begin{tabular}{cccccc}
\hline \multirow{2}{*}{ Parameter } & \multicolumn{5}{c}{ Building } \\
\cline { 2 - 6 } & $\mathrm{A}$ & $\mathrm{B}$ & $\mathrm{C}$ & $\mathrm{D}$ & $\mathrm{E}$ \\
\hline $\begin{array}{c}\boldsymbol{K}_{\boldsymbol{e}} \\
\mathrm{kN} / \mathrm{m}\end{array}$ & 19129.6 & 19043.4 & 19981.1 & 19601.1 & 19812.3 \\
\hline
\end{tabular}

\subsubsection{Base Shear Force}

The base shear force with the Direct Displacement Based Design (DDBD) method is given by the following equation:

$$
\mathrm{F}=\mathrm{V}_{\text {base }}=\mathrm{K}_{\mathrm{e}} \cdot \Delta_{\mathrm{d}}
$$

From (14), it can then be computed the magnitude of the base shear force in each building model and is tabulated in Table 12:

Table 12. Base Shear Force for Each Building Model

\begin{tabular}{cccccc}
\hline & \multicolumn{5}{c}{ Building } \\
\cline { 2 - 6 } Parameter & $\mathrm{A}$ & $\mathrm{B}$ & $\mathrm{C}$ & $\mathrm{D}$ & $\mathrm{E}$ \\
\hline $\begin{array}{c}\boldsymbol{V}_{\text {base }} \\
\mathrm{kN}\end{array}$ & 10216.9 & 10170.8 & 10671.6 & 10468.7 & 10581.5 \\
\hline
\end{tabular}
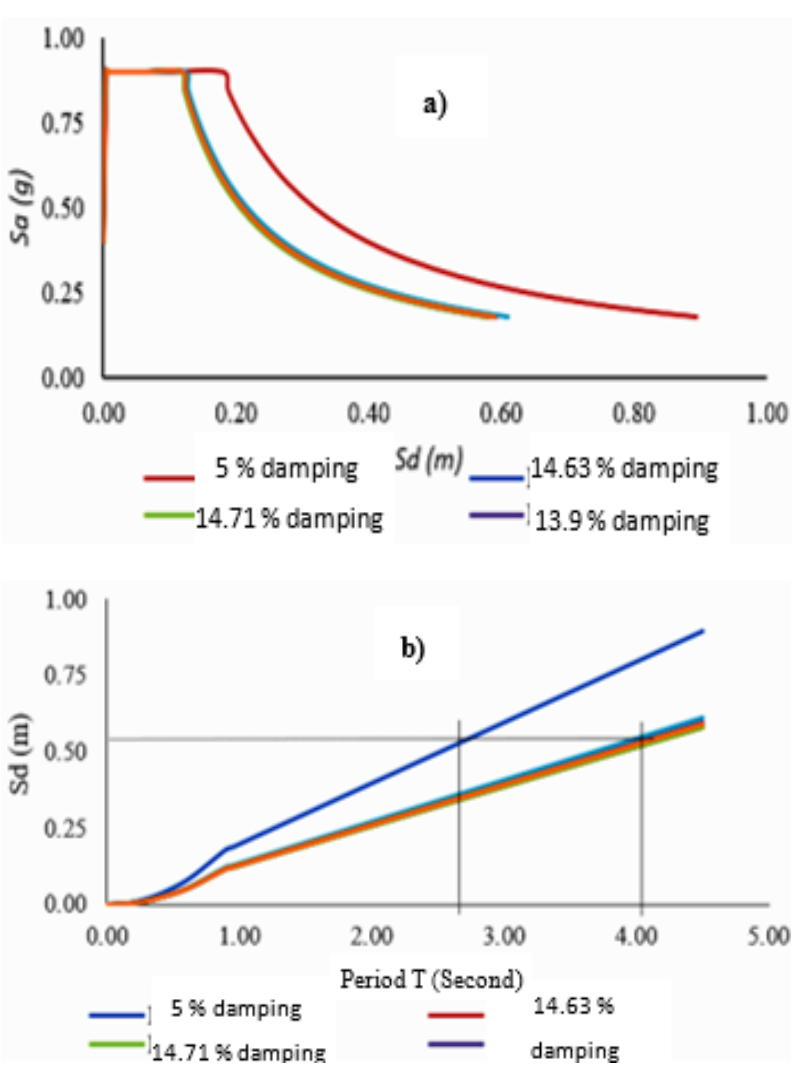

Figure 16. a) Response Spectrum Design at the Damping Level, and b) Spectra Displacement at the Damping Level of Each Building 


\subsection{Static Nonlinear Analysis}

Modeling nonlinearity properties of structural elements are based on preliminary which has been discussed in the previous stage. This modeling includes (1) plastic hinge of M3 beam flexural mechanism and (2) plastic hinge of PMM column interaction mechanisms. The deformation limit for each nonlinear property model corresponds to FEMA 356. The nonlinear property is then applied to the structural model for nonlinear static analysis (pushover), using the SAP 2000.

\subsection{Pushover Analysis Capacity Curve results}

The relationship of shear forces and displacement is reported in Figure 17. The $x$-axis represents the magnitude of the basic shear force needed to design a building, while the $y$-axis represents nonlinear deformation that occurs due to an increase in the force load given.

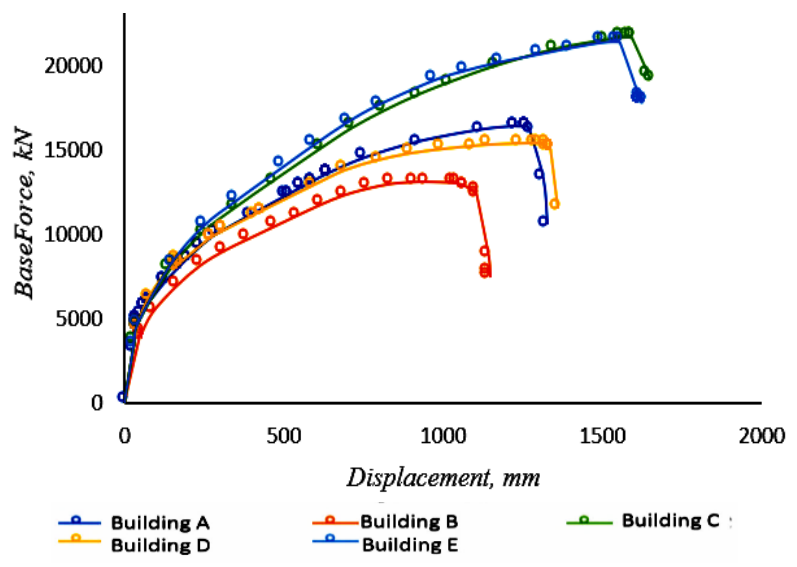

Figure 17. Pushover analysis capacity curve
Figure 17 shows that the largest deformation capacity is achieved by building $\mathrm{C}$ and building $\mathrm{E}$ with a maximum displacement target of up to $3 \%$. This value is the biggest one when compared to other models, in which building models $\mathrm{A}, \mathrm{B}$, and $\mathrm{D}$ produce maximum displacement targets of $2.2 \%, 2.0 \%$, and $2.3 \%$.

This proves that the deformation capacity is influenced by the column size and structure configuration where the largest deformation capacity is achieved by a medium-size column, namely buildings $\mathrm{C}$ and $\mathrm{E}$.

\subsection{Performance Evaluation and Plastification of Structures}

Structural performance evaluation is carried out using the ATC-40 capacity spectrum method (Figure 18) and the FEMA 356 displacement coefficient method so that the structure performance points are shown in Table 13. The performance points are used as a basis for determining the level of structural performance studied.

Table 13. Structural Performance Point

\begin{tabular}{ccc}
\hline \multirow{2}{*}{$\begin{array}{c}\text { Building } \\
\text { Model }\end{array}$} & \multicolumn{2}{c}{ Performance Point $(V(\mathrm{kN}), D(\mathrm{~m}))$} \\
\cline { 2 - 3 } & $\begin{array}{c}\text { Capacity Spectrum } \\
\text { ATC-40 }\end{array}$ & $\begin{array}{c}\text { Coefficient Method } \\
\text { FEMA-356 }\end{array}$ \\
\hline A & $(12304.24,0.507)$ & $(10757.33,0.358)$ \\
\hline B & $(11397.36,0.571)$ & $(10319.79,0.451)$ \\
\hline C & $(13710.90,0.507)$ & $(12771.65,0.398)$ \\
\hline D & $(12259.51,0.522)$ & $(11144.60,0.404)$ \\
\hline E & $(14079.51,0.500)$ & $(12740.62,0.402)$ \\
\hline
\end{tabular}

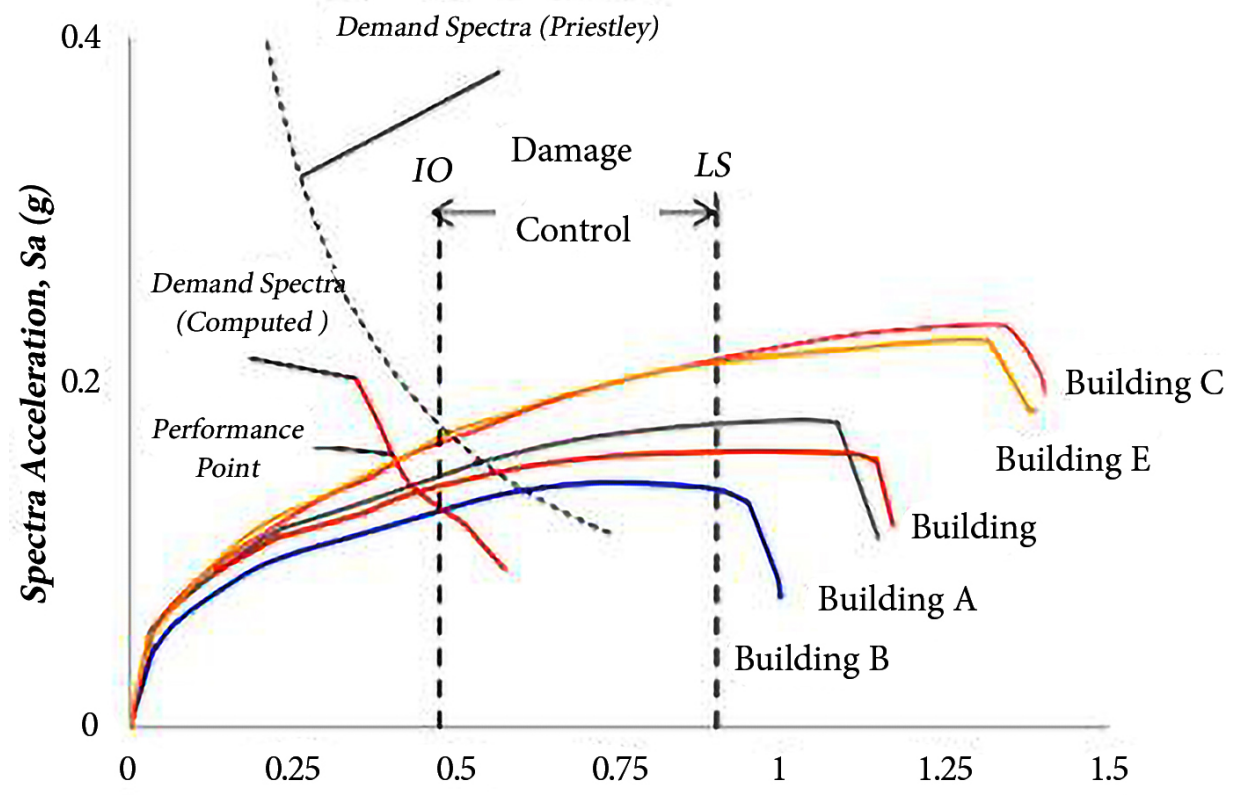

Figure 18. ATC-40 spectrum capacity 
Based on the ATC-40 global criteria, the performance levels of the five models are reported in Table 14. When referring to the 1997 FEMA 303/NEHRP assessment matrix in Figure 6, the maximum expected performance of office buildings (risk category 1) is Collapse Prevention (CP). Thus, it can be concluded that all study models meet these objectives.

Table 14. Structural Performance Level

\begin{tabular}{|c|c|c|c|c|}
\hline & \multirow{2}{*}{ Parameter } & \multirow{2}{*}{ DDBD } & \multicolumn{2}{|c|}{ Pushover } \\
\hline & & & ATC-40 & FEMA 356 \\
\hline \multirow{3}{*}{ A } & $\begin{array}{l}\text { Displacement Design } \\
(\mathrm{m})\end{array}$ & 0.534 & 0.507 & 0.358 \\
\hline & Drift ratio & - & 0.0095 & 0.0068 \\
\hline & Performance Level & $L S$ & IO & $I O$ \\
\hline \multirow{3}{*}{ B } & $\begin{array}{l}\text { Displacement Design } \\
(\mathrm{m})\end{array}$ & 0.534 & 0.571 & 0.451 \\
\hline & Drift ratio & - & 0.0107 & 0.0085 \\
\hline & Performance Level & $L S$ & $D C$ & $I O$ \\
\hline \multirow{3}{*}{$\mathrm{C}$} & $\begin{array}{l}\text { Displacement Design } \\
(\mathrm{m})\end{array}$ & 0.534 & 0.507 & 0.398 \\
\hline & Drift ratio & - & 0.0095 & 0.0075 \\
\hline & Performance Level & $L S$ & $I O$ & $I O$ \\
\hline \multirow{3}{*}{$\mathrm{D}$} & $\begin{array}{l}\text { Displacement Design } \\
(\mathrm{m})\end{array}$ & 0.534 & 0.522 & 0.404 \\
\hline & Drift ratio & - & 0.0095 & 0.0076 \\
\hline & Performance Level & $L S$ & $I O$ & $I O$ \\
\hline \multirow{3}{*}{ E } & $\begin{array}{l}\text { Displacement Design } \\
(\mathrm{m})\end{array}$ & 0.534 & 0.500 & 0.402 \\
\hline & Drift ratio & - & 0.0094 & 0.0076 \\
\hline & Performance Level & $L S$ & $I O$ & $I O$ \\
\hline
\end{tabular}

LS: Life Safety; IO: Immediate Occupancy; DC: Damage Control

On the other hand, the performance evaluation using the FEMA 356 displacement coefficient method shows a relatively smaller displacement target than the ATC-40 capacity spectrum method. This shows that there are differences in the criteria of the two methods. The results of the evaluation of the two methods present that the study model has a better performance than the maximum expectation, namely Immediate Occupancy.

Plastification that occurs in each study model has a relatively identical pattern. The differences that occur only include the percentage of plasticized structural elements. The percentage of plastification that occurs due to the excitation of incremental static load is reported in Figure 18. It can be seen that the maximum plastification that occurs in all study models exceeds the CP level, with a percentage of damage of $9.8 \%-12.5 \%$.

From Figure 19, it is observed that there are differences in the level of plasticity between study models. The E building model tends to have a greater degree of damage. However, the difference is not too significant, so this pushover analysis procedure is very suitable to be used to identify the level of damage to structural elements at the desired level of performance.

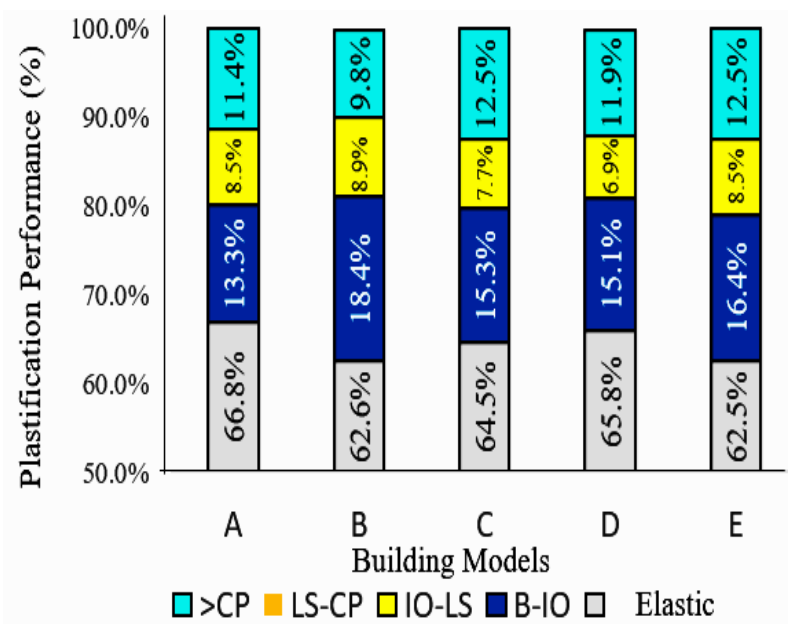

Figure 19. Plastification Performance Percentages of Structural Elements

Plastification of the structures when the level of performance reached is shown in Figure 20. The conditions shown in the figure are the result of pushover analysis. If observed, the plastification process in all study models starts from the lower floor beam element and gradually travels up to the next floor beam element along with the addition thrust load, followed by the formation of plasticized joints at the base end of the ground floor column. This shows that the concept of SCWB (Strong Column Weak Beam) is fulfilled.

\subsection{Drift and Displacement Comparison}

The discussion of previous evaluations shows that building models $\mathrm{C}$ and $\mathrm{E}$ are structural systems that are able to provide maximum deformation resistance. Furthermore, the performance-based design parameters are compared to the actual (both drift and displacement) results of the pushover analysis and the DDBD results (both drift and displacement) at the design performance level are life safety with an average drift ratio according to ATC-40 of $2 \%$. The drift and displacement results are reported in Figure 21.

The picture shows that the drift and displacement in all building models meet the results from the plan which is designed by the DDBD method. However, the $8^{\text {th }}$ to $15^{\text {th }}$-floor displacement of the pushover results show a smaller value to the DDBD design. This also applies to the story drift ratio value, wherefrom the picture represents the story drift ratio on the floor 4-15 value decreases. This is due to the typical structural stiffness of the structural elements.

From the picture, it can also be seen that the story drift ratio values in buildings $\mathrm{A}, \mathrm{C}, \mathrm{D}$, and $\mathrm{E}$ are still in the maximum level of performance expectations, namely Life Safety. However, in building B, the story drift ratio on $2^{\text {th }}$ and $3^{\text {th }}$ floors exceeds the level of life safety performance. This is

in line with what was discussed in the previous discussion 
where Building B has the lowest deformation capacity. Thus, it can be concluded that building model B occupies the lowest position when compared to the other 4 building models.

\subsection{Base Shear Force Comparison}

There are several methods for determining the magnitude of the seismic shear force on the structures. The previous section discussed methods for determining the base shear force using the DDBD method, and nonlinear static analysis (Pushover). In spite of that, it should be realized that the method is not yet considered in the earthquake SNI regulations. equivalent static methods and spectrum response methods are commonly castoff. In addition, this paper compares the magnitude of the base shear force obtained from the static method equivalent to the method discussed earlier.

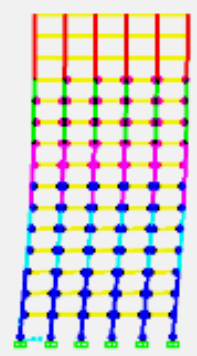

Line-1

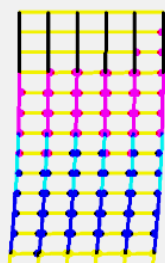

1! $!$ ! ! !

Line-1

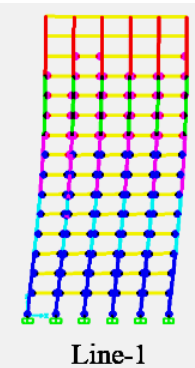

Line-1

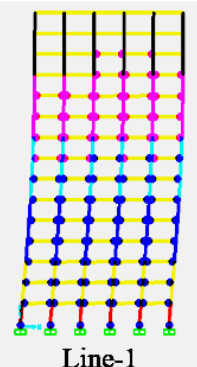

Line-1

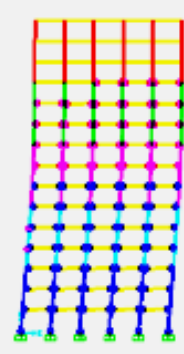

Line-2
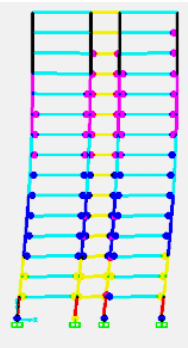

Line-2
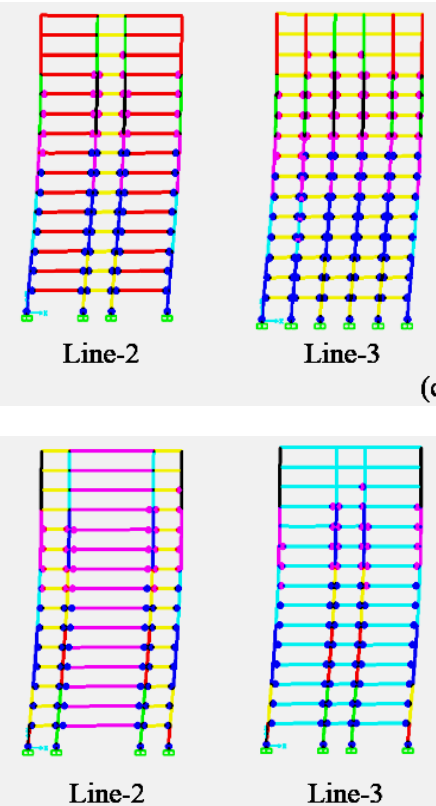

(d)

(a)

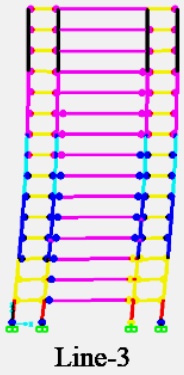

(b)

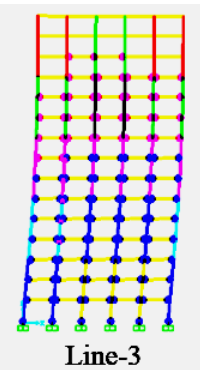

(c)
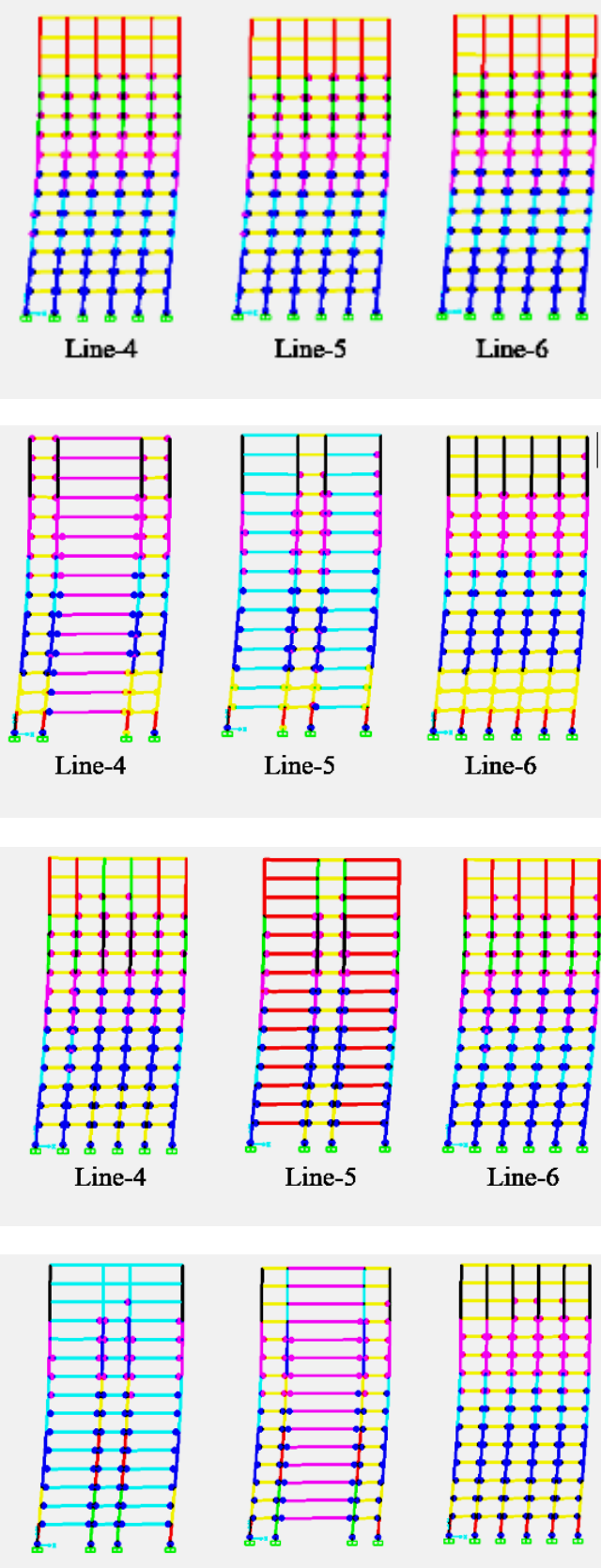

Line-4

Line-5

Line-6 


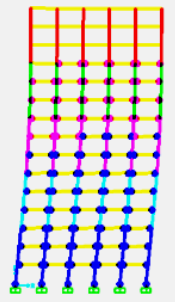

Line-1

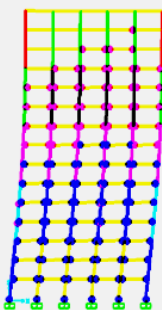

Line-2

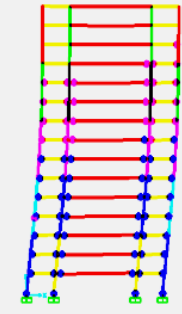

Line-3

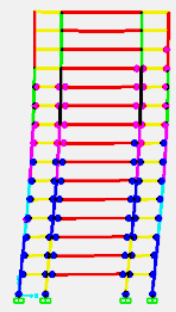

Line-4

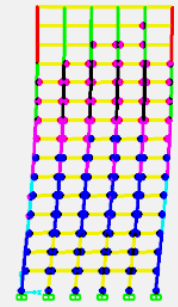

Line-5

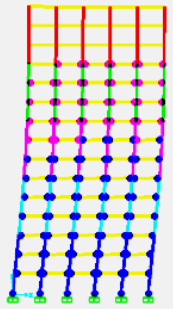

Line-6

(e)

Figure 20. Plastification of Building Models due to Static Pushover: a) Building Model A; b) Building Model B; c) Building Model C; d) Building Model D; e) Building Model E

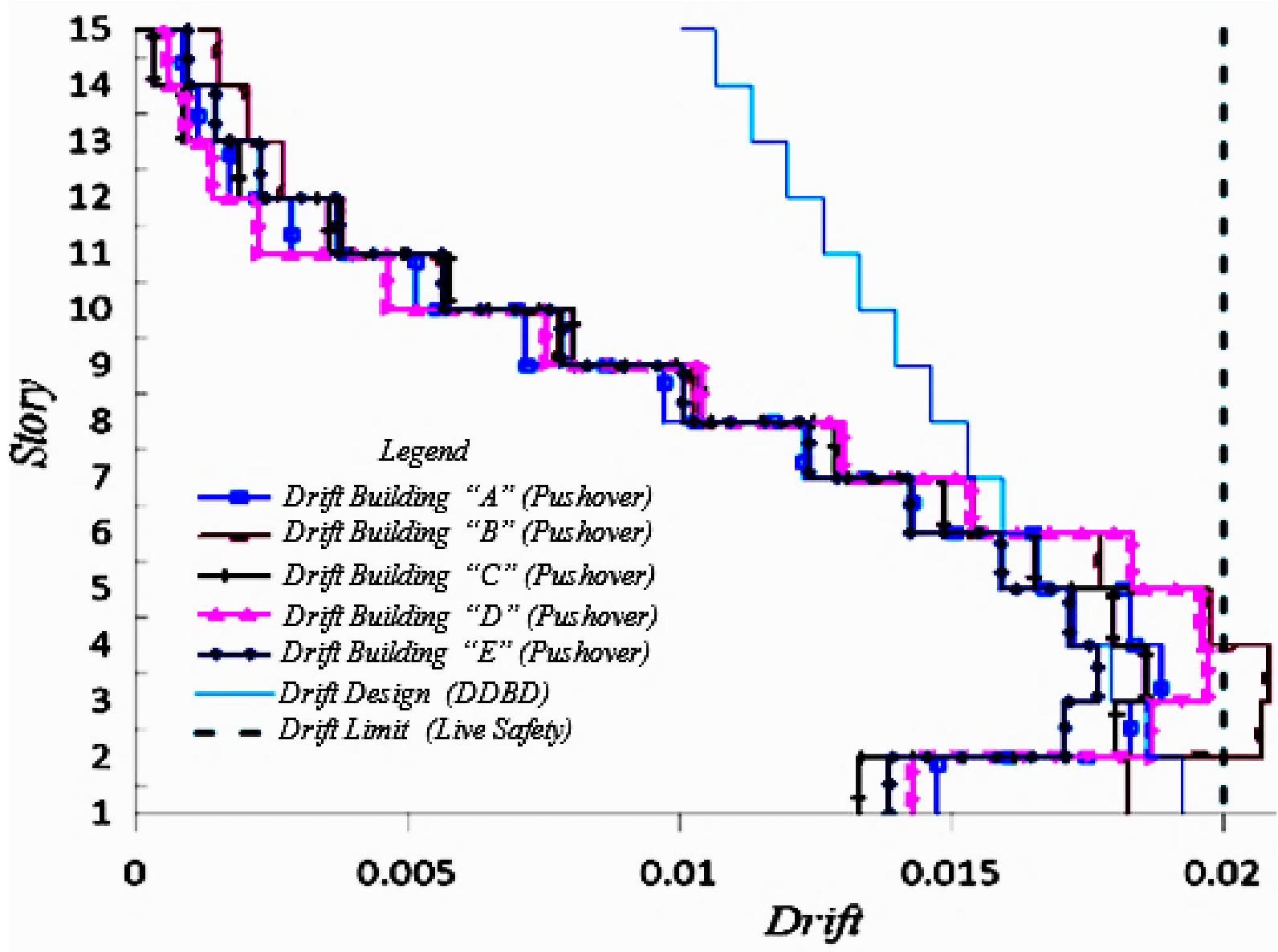

(a) 


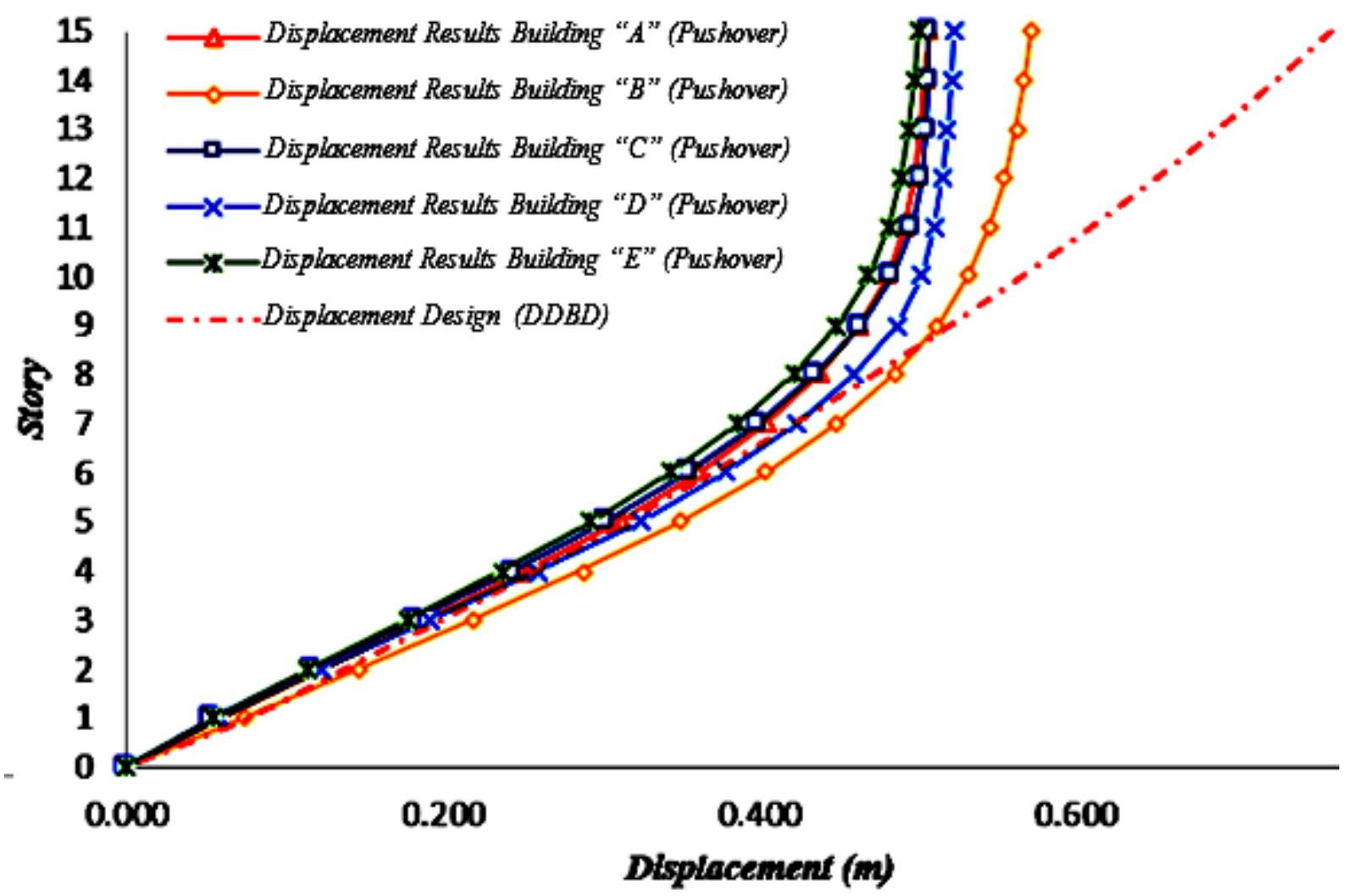

(b)

Figure 21. a) Drift Comparison; b) Displacement Comparison

The results of the base shear force analysis of each method are reported in Figure 22. It appears that there is a significant difference between the static equivalent method with the DDBD method and the pushover analysis results. This is due to the Cs limits required by Indonesian code SNI: 1726: 2012. On the other hand, the DDBD method is relatively close to the value of the base shear force of the pushover analysis results using both the ATC-40 and FEMA356 methods. This expressed the level of accuracy of the DDBD method proposed by Priestley (2007). However, please note that this DDBD method still requires verification globally to be accepted as a basis for calculating the base shear forces in the world seismic regulation.

Based on analysis, it can be concluded that the equivalent static method is not suitable for high-rise buildings, in view to the fact that high-rise buildings have a long period of natural vibration which causes the value of the Cs actual earthquake coefficient under Cs minimum, hence that it can cause the design of stiffness (cross-section) and strength design (reinforcement) to be conservative, uneconomic, and result in more dense reinforcement. 


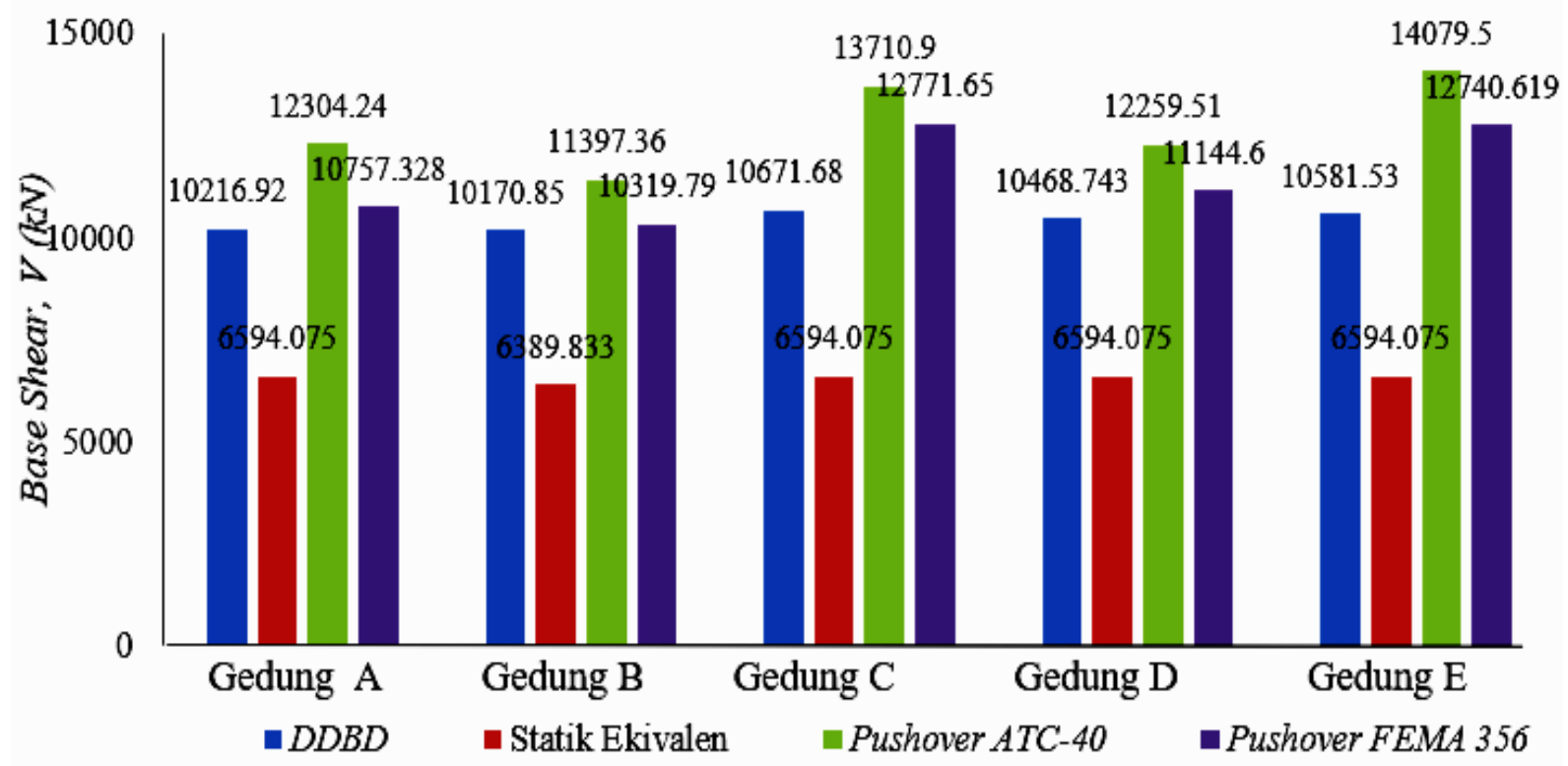

Figure 22. Base Shear Force Comparison

\subsection{Structural Response based on Indonesian Code SNI: 1726: 2012}

The structure response idealization aims to find out the structural response parameters of pushover analysis results based on Indonesian code SNI 1726: 2012, with applying the idealization approach in the force with a binary curve using the ASCE 41-13 method. The binary curve parameters are SAP2000 program outputs as shown in Table 15 .

Table 15. FEMA356 Linear Curve Parameter

\begin{tabular}{cccccc}
\hline \multirow{2}{*}{$\begin{array}{c}\text { Para- } \\
\text { meter }\end{array}$} & $\mathrm{A}$ & $\mathrm{B}$ & $\mathrm{C}$ & $\mathrm{D}$ & $\mathrm{E}$ \\
\cline { 2 - 6 } Sa & 0.537 & 0.468 & 0.532 & 0.524 & 0.523 \\
\hline Alpha & 0.121 & 1.106 & 0.152 & 1.270 & 0.153 \\
\hline$V_{y}(\mathrm{kN})$ & 6038 & 5362 & 5718 & 6329 & 6670 \\
\hline$V_{\text {target }}$ & 10757 & 10319 & 12771 & 11144 & 12740 \\
\hline Cm & 0.9 & 0.9 & 0.9 & 0.9 & 0.9 \\
\hline$\delta_{y}(\mathrm{~m})$ & 0.054 & 0.088 & 0.062 & 0.091 & 0.069 \\
\hline$\delta_{\max }(\mathrm{m})$ & 0.358 & 0.451 & 0.398 & 0.404 & 0.402 \\
\hline$W(\mathrm{kN})$ & 97257.38 & 97257 & 97257 & 97257 & 97257 \\
\hline
\end{tabular}

Based on the parameters as shown in Table 15, it can then be calculated the structural response parameters in each study model using equations sourced from ASCE 41-13 and tabulated in Table 16.

The structural response parameters as listed in Table 15 present values that are close to those listed in Indonesian code SNI 1726: 2012. Thus, this pushover analysis method is one alternative that can be applied by designers who want to know the structure's performance at its performance level.
Table 16. Structural Response Parameter

\begin{tabular}{ccccccc}
\hline \multirow{2}{*}{$\begin{array}{c}\text { Para- } \\
\text { meter }\end{array}$} & \multicolumn{5}{c}{ Pushover FEMA 356 } & \multirow{2}{*}{ SNI } \\
\cline { 2 - 6 } & $\mathrm{A}$ & $\mathrm{B}$ & $\mathrm{C}$ & $\mathrm{D}$ & $\mathrm{E}$ & \\
\hline$R$ & 7.79 & 7.64 & 8.14 & 7.25 & 7.59 & 8.00 \\
\hline$\Omega_{0}$ & 1.78 & 1.92 & 2.23 & 1.76 & 1.91 & 3.00 \\
\hline$C d$ & 6.62 & 5.12 & 6.42 & 4.44 & 5.82 & 5.50 \\
\hline
\end{tabular}

\section{Conclusions}

Based on the results, it can be concluded that

1) Both building structural models $\mathrm{C}$ and $\mathrm{E}$ provide the largest deformation capacity, which is able to achieve displacement targets of up to $1.6 \mathrm{~m}$.

2) The performance evaluation results show that all structural models have a level of performance that is better than maximum expectations, which is at the level of IO (Immediate Occupancy) performance.

3) The DDBD method results in a greater base shear force of $59 \%$ than the equivalent static method, a smaller $18 \%$ of the ATC-40 capacity spectrum method, and quite similar to the FEMA 356 displacement coefficient results.

4) The structural response parameters of the pushover analysis results present that each building model has different structural response parameter configurations but is close to the parameters in the Indonesian code SNI 1726: 2012 which is summarized in Table 15.

5) The structural performance results of the present study do not differ too much for each structural model. However, the structural deformation capacity is greatly affected by the column size. The pushover analysis results show that the largest deformation 
capacity is achieved by a medium-sized column with a displacement target of up to $3 \%$.

\section{REFERENCES}

[1] Kasimzade, A. A., Şafak, E., Ventura, C. E., Naeim, F., \& Mukai, Y. (2018). Seismic Isolation, Structural Health Monitoring, and Performance Based Seismic Design in Earthquake Engineering. Springer International Publishing; 2019. doi:10.1007/978-3-319-93157-9.

[2] Abhilash D.K, Dr. MD Vijayan (2019). Pushover Analysis of a Multi-Storied Building in Two Different Zones - Intl. Jour. of Inn. Res. in Sci., Eng. and Tech. Vol. 8, Issue 6, June

[3] Leslie, R., \& Naveen, A. P. (2017). A Study on Pushover Analysis using Capacity Spectrum Method based on Eurocode 8 . In $16^{\text {th }}$ World Conference on Earthquake Engineering, Reg Code: S-P148645023, Santiago, Chile.

[4] Sheth, R., Prajapati, J., \& Soni, D. (2018). Comparative study nonlinear static pushover analysis and displacement based adaptive pushover analysis method. International Journal of Structural Engineering, 9(1), 81-90.

[5] Abbasnia, R., Davoudi, A. T., \& Maddah, M. M. (2014). An improved displacement-based adaptive pushover procedure based on factor modal combination rule. Earthquake Engineering and Engineering Vibration, 13(2), 223-241.

[6] Abbasnia, R., Tajik Davoudi, A., \& Maddah, M. M. (2014). An improved displacement-based adaptive pushover procedure for the analysis of frame buildings. Journal of Earthquake Engineering, 18(7), 987-1008.

[7] Brozovič, M., \& Dolšek, M. (2014). Envelope-based pushover analysis procedure for the approximate seismic response analysis of buildings. Earthquake engineering \& structural dynamics, 43(1), 77-96.

[8] Dya, A.F.C., \& Oretaa, A. W. C. (2015). Seismic vulnerability assessment of soft story irregular buildings using pushover analysis. Procedia Engineering, 125, 925-932.

[9] Abou El-Ftooh, K., Seleemah, A. A., Atta, A. A., \& Taher, S. E.D. F. (2018). Does a Single ANN Properly Predict Pushover Response Parameters of Low-, Medium-and High-Rise Infilled RC Frames?. Arabian Journal for Science and Engineering, 43(10), 5517-5539.

[10] Hsiao, F. P., Oktavianus, Y., \& Ou, Y. C. (2015). A pushover seismic analysis method for asymmetric and tall buildings. Journal of the Chinese Institute of Engineers, 38(8), 991-1001.

[11] Louzai, A., \& Abed, A. (2015). Evaluation of the seismic behavior factor of reinforced concrete frame structures based on comparative analysis between non-linear static pushover and incremental dynamic analyses. Bulletin of Earthquake Engineering, 13(6), 1773-1793.

[12] Manoukas, G. (2019). Evaluation of a multimode pushover procedure for asymmetric and non-regular in plan reinforced concrete buildings under biaxial seismic excitation. Inter. Journal of Structural Engineering, 10(1), 61-76.
[13] Panyakapo, P. (2014). Cyclic pushover analysis procedure to estimate seismic demands for buildings. Engineering Structures, 66, 10-23.

[14] Qu, Y., Luo, Y., Zhu, Z., \& Huang, Q. (2019). An improved multidimensional modal pushover analysis procedure for seismic evaluation of latticed arch-type structures under lateral and vertical earthquakes. The Structural Design of Tall and Special Buildings, 28(10), e1618.

[15] Qu, C., \& Zhou, Y. (2020). A new lateral load pattern for pushover analysis of asymmetric-plan structures. Journal of Vibroengineering, 22(5), 1113-1125.

[16] Baghaei, H., \& Razani, R. (2019). Method of Pushunder Analysis (PUA) for Approximate Seismic Analysis of Structures Using Various Patterns of Stepwise Increasing Base Acceleration and Its Comparison with Pushover Analysis (POA). Civil Engineering and Architecture Vol. 7(2), pp. $49-63$

[17] Taranath, B. S. (2010). Wind and earthquake resistant buildings. Marcell Decker, New York..

[18] Badan-Standarisasi-Nasional. Tata Cara Perencanaan Ketahanan Gempa untuk Bangunan Gedung (SNI 1726:2002). Jakarta: 2012.

[19] Hejazi, F., \& Karimzadeh, K. (2018). Analysis Procedure for Earthquake Resistant Structures. Springer.

[20] Papazafeiropoulos, G., Plevris,V., \& Papadrakakis,M. (2017). A new energy-based structural design optimization concept under seismic actions. Frontiers in Built Environment, 3, 44.

[21] Ranaweera, K. K. P. A., Lilushan, W. R., Randenigama, D. M. W. L., \& Wijesundara, K. K. (2017). The Structural Analysis of King Parakramabahu's Palace. Civil Engineering and Architecture Vol. 5(5), pp. 180 - 184

[22] Jan J, Pandaleke SRE, Pangouw JD, Khosama LK. (2013). Perencanaan Sistem Rangka Pemikul Momen Khusus Pada Komponen Balok-Kolom Dan Sambungan Struktur Baja Gedung BPJN XI. J Sipil Statik 2013;1:653-63.

[23] Vision 2000 Committee, \& California. Office of Emergency Services. (1995). Performance Based Seismic Engineering of Buildings: pt. 3. Preliminary Northridge lessons. pt. 4. Moving the blue book toward performance based engineering (Vol. 2). Structural Engineers Association of California.

[24] BSSC, N. (1997). Recommended provisions for seismic regulation for new buildings and other structures, 1997 edition, Part 2: Commentary FEMA 303. Washington, DC: Federal Emergency Management Agency.

[25] Prestandard, F. E. M. A. (2000). commentary for the seismic rehabilitation of buildings (FEMA356). Washington, DC: Federal Emergency Management Agency, 7.

[26] FEMA, A. (2005). 440, Improvement of nonlinear static seismic analysis procedures. FEMA-440, Redwood City, 7(9), 11.

[27] ATC, S. (1996). Evaluation and retrofit of concrete buildings, Rep. ATC-40, Applied Technology Council, Redwood City, California.

[28] Calvi, G. M., Priestley, M. J. N., \& Kowalsky, M. J. (2007). 
Displacement-based seismic design of structures. Earthquake Spectra, 24(2), 1-24.

[29] American Society of Civil Engineers. (2013). Minimum Design Loads for Buildings and Other Structures (ASCE/SEI 7-10). American Society of Civil Engineers..

[30] FEMA-451. NEHRP Recommended Provisions for Seismic
Regulation for New Buildings and Other Structure and Accompanying Commentary and Maps. Washington D.C.: 2006

[31] Latifi, R., \& Rouhi, R. (2020). Three-Dimensional Numerical Model for Seismic Analysis of Structures. Civil Engineering and Architecture Vol. 8(3), pp. 237 - 245. 